KARL E. CASE

Wellesley College

ROBERT J. SHILLER

Yale University

\title{
Is There a Bubble in the Housing Market?
}

THE POPULAR PRESS is full of speculation that the United States, as well as other countries, is in a "housing bubble" that is about to burst. Barrons, Money magazine, and The Economist have all run recent feature stories about the irrational run-up in home prices and the potential for a crash. The Economist has published a series of articles with titles like "Castles in Hot Air," "House of Cards," "Bubble Trouble," and "Betting the House." These accounts have necessarily raised concerns among the general public. But how do we know if the housing market is in a bubble?

The term "bubble" is widely used but rarely clearly defined. We believe that in its widespread use the term refers to a situation in which excessive public expectations of future price increases cause prices to be temporarily elevated. During a housing price bubble, homebuyers think that a home that they would normally consider too expensive for them is now an acceptable purchase because they will be compensated by significant further price increases. They will not need to save as much as they otherwise might, because they expect the increased value of their home to do the saving for them. First-time homebuyers may also worry during a housing bubble that if they do not buy now, they will not be able to afford a home later. Furthermore, the expectation of large price increases may have a strong impact on demand if people think that home prices are very unlikely to fall, and certainly not likely to fall for long, so that there is little perceived risk associated with an investment in a home.

We are grateful for generous research support from Wellesley College and are indebted to Sonyay Lai, Semida Munteanu, and Xin Yu for excellent research assistance. Fiserv CSW, Inc. has supplied us with important data and assistance. 
If expectations of rapid and steady future price increases are important motivating factors for buyers, then home prices are inherently unstable. Prices cannot go up rapidly forever, and when people perceive that prices have stopped going up, this support for their acceptance of high home prices could break down. Prices could then fall as a result of diminished demand: the bubble bursts.

At least one aspect of a housing bubble - the rapid price increaseshas clearly been seen recently. A rapid surge in home prices after 2000, as tabulated, for example, by the Economist Intelligence Service, has been seen in almost all the advanced economies of the world, with the exception of Germany and Japan. In some of these countries, price-to-rental ratios and price-to-average income ratios are at levels not seen since their data begin in $1975 .{ }^{1}$

But the mere fact of rapid price increases is not in itself conclusive evidence of a bubble. The basic questions that still must be answered are whether expectations of large future price increases are sustaining the market, whether these expectations are salient enough to generate anxieties among potential homebuyers, and whether there is sufficient confidence in such expectations to motivate action.

In addition, changes in fundamentals may explain much of the increase. As we will show, income growth alone explains the pattern of recent home price increases in most states. Falling interest rates clearly explain much of the recent run-up nationally; they can also explain some of the cross-state variation in appreciation because of differences in the elasticities of supply of homes, including land.

To shed light on whether the current boom is a bubble and whether it is likely to burst or deflate, we present two pieces of new evidence. First, we analyze U.S. state-level data on home prices and the "fundamentals," including income, over a period of seventy-one quarters from 1985 to 2002.

Second, we present the results of a new questionnaire survey conducted in 2003 of people who bought homes in 2002 in four metropolitan areas: Los Angeles, San Francisco, Boston, and Milwaukee. The survey replicates one we did in these same metropolitan areas in 1988, during another purported housing bubble, after which prices did indeed fall sharply in many cities. The results of the new survey thus allow compari-

1. "Castles in Hot Air," The Economist, May 28, 2003. 
son of the present situation with that one. Our survey also allows us to compare metropolitan areas that have reputedly gone through a bubble recently (Los Angeles, San Francisco, and Boston) with one that has not (Milwaukee).

The notion of a bubble is really defined in terms of people's thinking: their expectations about future price increases, their theories about the risk of falling prices, and their worries about being priced out of the housing market in the future if they do not buy. Economists rarely ask people what they are thinking when they make economic decisions, and some economists have argued that one should never do so. ${ }^{2} \mathrm{We}$ disagree. If questions are carefully worded and people are surveyed at a time close to their making an actual economic decision, then by making comparisons across time and economic circumstances, we can learn about how the decisions are made. ${ }^{3}$

\section{On the Origin of the Term "Housing Bubble"}

There is very little agreement about housing bubbles. In fact, the widespread use of the term "housing bubble" is itself quite new. Figure 1 shows a monthly count since 1980 of stories incorporating the words "housing bubble" in major newspapers in the English language around the world, as tabulated using Lexis-Nexis. (The data in years before 2003 are rescaled to account for the smaller coverage of Lexis-Nexis in earlier years.) The term "housing bubble" had virtually no currency until 2002, when its use suddenly increased dramatically, even though the run-up in real estate prices in the 1980s was as big as that since 1995. The peak in usage of "housing bubble" occurred in October 2002. The only real evidence of its currency before 2002 is a few uses of the term just after the stock market crash of 1987, but that usage quickly died out.

The term "housing boom" has appeared much more frequently since 1980. As figure 1 also shows, the use of this term was fairly steady from 1980 through 2001, although it, too, took off in 2002, also peaking in October. The term "boom" is much more neutral than "bubble" and suggests that the rise in prices may be an opportunity for investors. In contrast,

2. See Friedman (1953).

3. See Bewley (2002). 
Figure 1. Appearances of "Housing Bubble" and "Housing Boom" in U.S. Newspapers and Wire Services, 1980-2003 ${ }^{\mathrm{a}}$

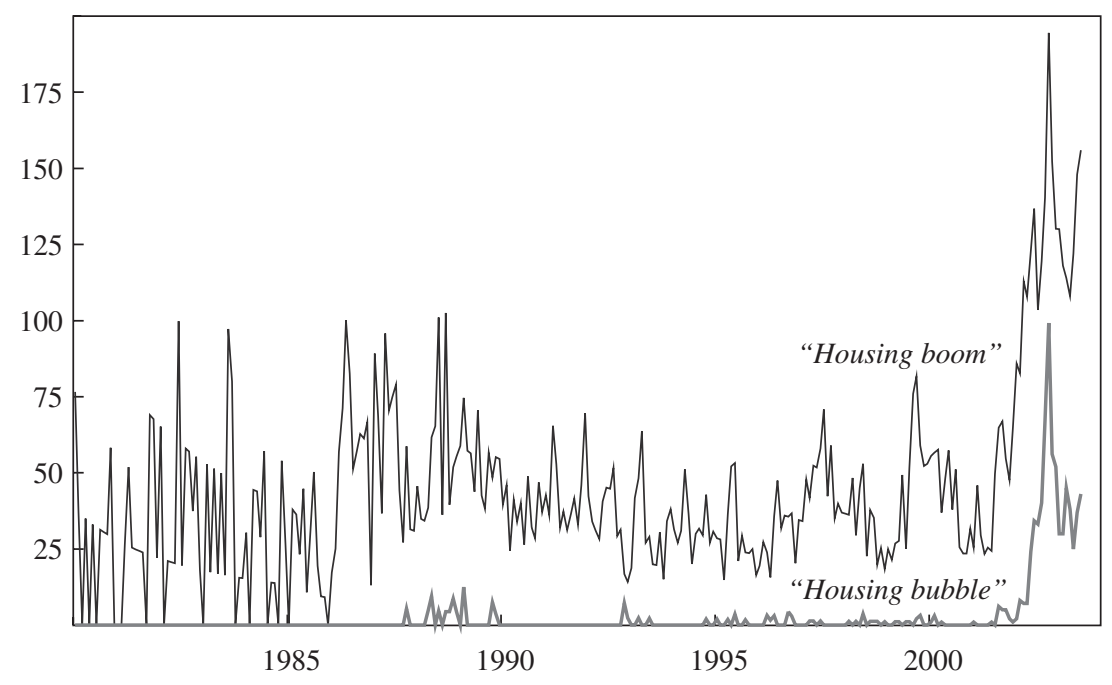

Source: Lexis-Nexis.

a. Data cover January 1980 through July 2003. They are rescaled for changes in the size of the database.

the term "bubble" connotes a negative judgment on the phenomenon, an opinion that price levels cannot be sustained.

Perhaps journalists are shy about using the word "bubble" except after some salient public event that legitimizes the possibility, such as the stock market crash of 1987 or that after 2000. The question is whether such journalistic use of the term also infects the thinking of homebuyers: do homebuyers think that they are in a bubble?

\section{The Previous "Housing Bubble"}

The period of the 1980s and the declines in housing prices in many cities in the early 1990s are now widely looked back upon as an example, even a model, of a boom cycle that led to a bust. A pattern of sharp price increases, with a peak around 1990 followed by a decline in many important cities around the world, including Boston, Los Angeles, London, Sydney, and Tokyo, looks consistent with a bubble. 
Housing prices began rising rapidly in Boston in 1984. In 1985 alone, home prices in the Boston metropolitan area went up 39 percent. In a 1986 paper, Case constructed repeat-sales indexes to measure the extent of the boom in constant-quality home prices. ${ }^{4}$ The same paper reported that a structural supply-and-demand model, which explained home price movements over ten years and across ten cities, failed to explain what was going on in Boston. The model predicted that income growth, employment growth, interest rates, construction costs, and other fundamentals should have pushed Boston housing prices up by about 15 percent. Instead, they went up over 140 percent before topping out in 1988. The paper ended with the conjecture that the boom was at least in part a bubble.

The following year we described price changes by constructing a set of repeat-sales indexes from large databases of transactions in Atlanta, Chicago, Dallas, and San Francisco. ${ }^{5}$ We used these indexes in a subsequent paper to provide evidence of positive serial correlation in the changes in real home prices. ${ }^{6}$ In fact, that paper showed that a change in price observed over one year tends to be followed by a change in the same direction the following year between 25 and 50 percent as large. The paper found evidence of inertia in excess returns as well. This strong serial correlation of price changes is certainly consistent with our expectation of a bubble. ${ }^{7}$

During the 1980s, spectacular home price booms in California and the Northeast helped stimulate the underlying economy on the way up, but they ultimately encountered a substantial drop in demand in the late 1980s and contributed significantly to severe regional recessions in the early 1990s. The end of the 1980s boom led to sharp price declines in some, but not all, cities.

Since 1995, U.S. housing prices have been rising faster than incomes and faster than other prices in virtually every metropolitan area. Despite

4. Case (1986).

5. Case and Shiller (1987).

6. Case and Shiller (1989).

7. Case and Shiller (1990) used time-series and cross-sectional regressions to test for the forecastability of prices and excess returns, using a number of independent variables. We found that the ratio of construction costs to price, changes in the adult population, and increases in real income per capita are all positively related to home prices and excess returns. The results add weight to the argument that the market for single-family homes is inefficient. 
the fact that the economy was in recession from March to November of 2001, and despite the loss of nearly 3 million jobs since 2000, prices of single-family homes, the volume of existing home sales, and the number of housing starts in the United States have remained at near-record levels. There can be no doubt that the housing market and spending related to housing sales have kept the U.S. economy growing and have prevented a double-dip recession since 2001.

The big question is whether there is reason to think that such a run-up in prices will be followed by a similar or even worse decline than the last time. To answer this question, we need to try to understand better the causes of these large movements in the housing market.

\section{Home Prices and the Fundamentals, 1985-2002}

A fundamental issue to consider when judging the plausibility of bubble theories is the stability of the relationship between income and other fundamentals and home prices over time and space. Here we look at the relationship between home price and personal income per capita and a number of other variables by state, using quarterly data from 1985:1 to 2002:3. The data contain 3,621 observations covering all fifty states and the District of Columbia. ${ }^{8}$

\section{Measures of Home Prices}

The series of home values was constructed from repeat-sales price indexes applied to the 2000 census median values by state. Case-Shiller (CS) weighted repeat-sales indexes constructed by Fiserv CSW Inc. are available for sixteen states. ${ }^{9}$ In addition, the Office of Federal Housing Enterprise Oversight (OFHEO) makes state-level repeat-value indexes produced by Fannie Mae and Freddie Mac available for all states.

The Case-Shiller indexes are the best available for our purposes, and wherever possible we use them. Although OFHEO uses a similar index construction methodology (the weighted repeat-sales method of Case and

8. The analysis and conclusions are consistent with Malpezzi's (1999) model of home prices estimated with data for 1979 through 1996.

9. See Case and Shiller $(1987,1989)$ on the construction of these indexes. 
Shiller),$^{10}$ their indexes are in part based on appraisals rather than exclusively on arm's-length transactions. CS indexes use controls, to the extent possible, for changes in property characteristics, and it can be shown that they pick up turns in price direction earlier and more accurately than do the OFHEO indexes. Nonetheless, for capturing broad movements over long periods, the indexes tend to track each other quite well, and OFHEO indexes are used in most states to achieve broader coverage.

The panel on home prices was constructed as follows for each state:

$$
V_{i}^{t}=V_{i}^{1999: 1} I_{i}^{t},
$$

where

$V_{i}^{t} \quad=$ adjusted median home value in state $i$ at time $t$

$V_{i}^{1999: 1}=$ median value of owner-occupied homes in state $i$ in 1999:1

$I_{i}^{t} \quad=$ weighted repeat-sales price index for state $i$ at time $t$, 1999:1 = 1.0.

The baseline figures for state-level median home prices are based on owner estimates in the 2000 census. A number of studies have attempted to measure the bias in such estimates. The estimates range from -2 percent to +6 percent. ${ }^{11}$

\section{Measures of the Fundamentals}

Data on personal income per capita by state are available from the Bureau of Economic Analysis website. The series is a consistent time series produced on a timely (monthly) schedule.

Population figures by state are not easy to obtain on a quarterly basis. The most carefully constructed series that we could find was put together by Economy.com (formerly Regional Financial Associates).

The most stable and reliable measure of employment at the state level is the nonfarm payroll employment series from the Bureau of Labor Statistics (BLS) Establishment Survey, which is available monthly, and which we have converted to quarterly data.

10. Case and Shiller (1987).

11. The -2 percent estimates are from Kain and Quigley (1972) and Follain and Malpezzi (1981) and the +6 percent estimate is from Goodman and Ittner (1992). 
The unemployment rate by state is available monthly from the BLS as part of its Household Survey.

Data on housing starts are not generally available by state before 1995 . The series used here was produced by Economy.com based on the historical relationship between permits and starts and a proprietary data base on permits.

Data on average mortgage interest rates on thirty-year fixed rate mortgages, assuming payment of 2 points ( 2 percent of the loan value) and an 80 percent loan-to-value ratio, are available from Fannie Mae.

For each quarter the ratio of income to mortgage payment per $\$ 1,000$ borrowed was calculated by dividing annual income per capita by twelve (to convert it to monthly) and then dividing by the monthly mortgage payment per $\$ 1,000$ of loan value for a thirty-year fixed rate with 2 points.

\section{Home Prices and Income: A First Look}

Table 1 presents ratios of home price to annual income per capita for the eight states where prices have been most volatile and the seven states where they have been least volatile. The least volatile states exhibit remarkable stability and very low ratios. The ratio for Wisconsin, for example, a state that we will explore at some length later, remains between 2.1 and 2.4 for the entire eighteen years of our sample. A simple regression of home prices on income per capita in Wisconsin generates an $R^{2}$ of 0.99 .

On the other hand, the eight most volatile states exhibit equally remarkable instability. Connecticut's ratio, for example, varies between 4.5 and 7.8 , and we find that income explains only 45 percent of the variation in home prices. Table 2 shows the variation for all fifty states and the District of Columbia. Glancing down the table reveals that forty-three of the fifty-one observations have a standard deviation below 0.41 , whereas only those eight states listed in table 1 as most volatile have standard deviations above 0.41 . These calculations reveal that states seem to fall into one of two categories. In the vast majority of states, prices move very much in line with income. But in New England, New York, New Jersey, California, and Hawaii, prices are significantly more volatile.

Plots of the ratio of price to income per capita for the states of California, Massachusetts, and Wisconsin (figure 2) show clearly that the pattern 
Table 1. Ratio of Average Home Price to Personal Income per Capita and Results of Regressions Explaining Home Prices, Selected States, 1985-2002

\begin{tabular}{|c|c|c|c|c|c|c|c|}
\hline \multirow[b]{3}{*}{ State } & \multirow{2}{*}{\multicolumn{4}{|c|}{ Ratio }} & \multirow[b]{3}{*}{$\begin{array}{l}\text { Quarter } \\
\text { of peak }\end{array}$} & \multicolumn{2}{|c|}{$\begin{array}{c}R^{2} \text { of regression of } \\
\text { home price on }\end{array}$} \\
\hline & & & & & & \multirow{2}{*}{$\begin{array}{c}\text { Income } \\
\text { per } \\
\text { capita }\end{array}$} & \multirow{2}{*}{$\begin{array}{c}\text { Other } \\
\text { fundamental } \\
\text { variables }^{\mathrm{b}}\end{array}$} \\
\hline & Trough & Peak & $\begin{array}{l}\text { Standard } \\
\text { deviation }\end{array}$ & $\begin{array}{c}I n \\
2002: 3\end{array}$ & & & \\
\hline \multicolumn{8}{|c|}{ States with most volatile home prices } \\
\hline Hawaii & 7.8 & 12.5 & 1.34 & 10.1 & 1992:3 & 0.83 & 0.89 \\
\hline Connecticut & 4.5 & 7.8 & 1.06 & 5.4 & 1988:1 & 0.45 & 0.69 \\
\hline New Hampshire & 4.0 & 6.6 & 0.84 & 5.3 & 1987:2 & 0.49 & 0.78 \\
\hline California & 6.0 & 8.6 & 0.80 & 8.3 & 1989:4 & 0.78 & 0.89 \\
\hline Rhode Island & 4.6 & 7.1 & 0.75 & 6.1 & 1988:1 & 0.65 & 0.79 \\
\hline Massachusetts & 4.3 & 6.6 & 0.72 & 5.9 & $1987: 3$ & 0.70 & 0.88 \\
\hline New Jersey & 4.5 & 6.8 & 0.68 & 5.6 & $1987: 3$ & 0.73 & 0.90 \\
\hline New York & 3.8 & 5.6 & 0.52 & 4.9 & 1987:3 & 0.77 & 0.86 \\
\hline \multicolumn{8}{|c|}{ States with least volatile home prices } \\
\hline Nebraska & 1.8 & 2.1 & 0.09 & 1.9 & $1985: 2$ & 0.96 & 0.99 \\
\hline Wisconsin & 2.1 & 2.4 & 0.08 & 2.4 & 2002:3 & 0.99 & 0.99 \\
\hline Illinois & 2.6 & 2.9 & 0.08 & 2.9 & 2002:3 & 0.98 & 0.99 \\
\hline Kentucky & 2.1 & 2.4 & 0.08 & 2.2 & 1985:1 & 0.99 & 0.99 \\
\hline Indiana & 2.0 & 2.3 & 0.06 & 2.1 & $1986: 4$ & 0.99 & 0.99 \\
\hline Iowa & 1.7 & 1.9 & 0.06 & 1.8 & $2002: 3$ & 0.98 & 0.99 \\
\hline Ohio & 2.3 & 2.5 & 0.04 & 2.5 & $2002: 3$ & 0.99 & 0.99 \\
\hline
\end{tabular}

of variation is anything but a random walk. In California and Massachusetts the pattern is one of a long inertial upswing followed by a long inertial downturn followed by another rise that has now lasted several years. In Wisconsin the ratio is much smaller and remarkably stable.

We conclude that whereas income alone almost completely explains home price increases in the vast majority of states, about eight states are characterized by large swings in home prices that exhibit strong inertia and cannot be well explained by income patterns.

\section{Home Prices and Other Fundamentals}

To explore the relationship between housing prices and other fundamental variables, we performed linear and log-linear reduced-form 
Table 2. Ratio of Home Price to Personal Income per Capita, All States, 1985-2002

\begin{tabular}{lccccr}
\hline State & & & & Standard & \\
Hedian & Trough & Peak & deviation & Mean \\
Hawaii & 9.79 & 7.83 & 12.50 & 1.34 & 10.03 \\
Connecticut & 5.41 & 4.47 & 7.84 & 1.06 & 5.67 \\
New Hampshire & 4.68 & 3.98 & 6.63 & 0.84 & 4.94 \\
California & 6.76 & 5.96 & 8.57 & 0.80 & 7.07 \\
Rhode Island & 5.49 & 4.58 & 7.12 & 0.75 & 5.62 \\
Massachusetts & 4.97 & 4.34 & 6.60 & 0.72 & 5.20 \\
New Jersey & 5.25 & 4.48 & 6.77 & 0.68 & 5.34 \\
New York & 4.54 & 3.83 & 5.60 & 0.52 & 4.55 \\
Texas & 2.48 & 2.20 & 3.59 & 0.41 & 2.61 \\
Maine & 3.98 & 3.44 & 4.77 & 0.40 & 3.98 \\
District of Columbia & 3.61 & 3.10 & 4.52 & 0.37 & 3.66 \\
Vermont & 4.11 & 3.64 & 4.85 & 0.37 & 4.19 \\
Louisiana & 2.56 & 2.42 & 3.53 & 0.33 & 2.70 \\
Alaska & 3.26 & 2.48 & 4.07 & 0.33 & 3.29 \\
Oregon & 2.25 & 1.49 & 2.69 & 0.32 & 2.23 \\
Utah & 2.87 & 2.29 & 3.21 & 0.31 & 2.81 \\
Mississippi & 2.28 & 2.21 & 3.15 & 0.29 & 2.43 \\
Maryland & 4.01 & 3.62 & 4.69 & 0.29 & 4.05 \\
Oklahoma & 2.13 & 2.05 & 3.04 & 0.28 & 2.25 \\
Washington & 3.12 & 2.28 & 3.36 & 0.26 & 3.00 \\
Delaware & 3.62 & 3.33 & 4.14 & 0.26 & 3.69 \\
Colorado & 2.60 & 2.19 & 3.18 & 0.25 & 2.57 \\
Virginia & 3.47 & 3.04 & 3.87 & 0.24 & 3.44 \\
Georgia & 2.76 & 2.58 & 3.25 & 0.23 & 2.83 \\
Arizona & 3.53 & 3.38 & 4.17 & 0.22 & 3.63 \\
North Dakota & 2.24 & 2.05 & 2.98 & 0.22 & 2.32 \\
Arkansas & 2.22 & 2.13 & 2.84 & 0.22 & 2.33 \\
& & & & & (continued) \\
& & & & &
\end{tabular}

regressions with three dependent variables: the level of home prices, the quarter-to-quarter change in home prices, and the price-to-income ratio described above. The results for the linear versions of these regressions are given in tables 1 and 3; the results for the log-linear regressions are similar. In those states where income and home prices are very highly correlated, the addition of mortgage rates, housing starts, employment, and unemployment to the regression added little explanatory power. However, for the eight states where income is a less powerful predictor of home prices, the addition of changes in population, changes in employment, the mortgage rate, unemployment, housing starts, and the ratio of income to mortgage payment per $\$ 1,000$ borrowed added significantly to the $R^{2}$ (table 1 ).

Table 3 reports the pattern of significant coefficients for three sets of regressions on data from the eight states where price-to-income ratios are 
Table 2. Ratio of Home Price to Personal Income per Capita, All States, 1985-2002 (continued)

\begin{tabular}{lccccr}
\hline State & Median & Trough & Peak & $\begin{array}{r}\text { Standard } \\
\text { deviation }\end{array}$ & Mean \\
\hline Montana & 2.55 & 2.02 & 2.71 & 0.22 & 2.44 \\
Florida & 3.04 & 2.80 & 3.51 & 0.21 & 3.08 \\
Missouri & 2.32 & 1.18 & 2.71 & 0.21 & 2.38 \\
Pennsylvania & 2.70 & 2.43 & 3.14 & 0.21 & 2.73 \\
Wyoming & 2.12 & 1.82 & 2.65 & 0.21 & 2.15 \\
New Mexico & 3.38 & 3.12 & 3.85 & 0.20 & 3.40 \\
Tennessee & 2.35 & 2.23 & 2.80 & 0.19 & 2.43 \\
Nevada & 3.56 & 3.32 & 3.97 & 0.18 & 3.59 \\
Alabama & 2.38 & 2.31 & 2.84 & 0.17 & 2.47 \\
Michigan & 1.93 & 1.69 & 2.37 & 0.17 & 1.98 \\
Minnesota & 2.40 & 2.27 & 2.92 & 0.16 & 2.47 \\
North Carolina & 2.60 & 2.50 & 2.98 & 0.16 & 2.67 \\
Idaho & 2.58 & 2.27 & 2.91 & 0.15 & 2.58 \\
West Virginia & 2.32 & 2.22 & 2.79 & 0.15 & 2.38 \\
South Carolina & 2.69 & 2.57 & 3.06 & 0.15 & 2.74 \\
Kansas & 1.97 & 1.84 & 2.30 & 0.14 & 2.02 \\
South Dakota & 1.87 & 1.73 & 2.20 & 0.11 & 1.89 \\
Nebraska & 1.88 & 1.76 & 2.12 & 0.09 & 1.89 \\
Illinois & 2.74 & 2.57 & 2.87 & 0.08 & 2.73 \\
Wisconsin & 2.26 & 2.12 & 2.44 & 0.08 & 2.25 \\
Kentucky & 2.21 & 2.11 & 2.41 & 0.08 & 2.23 \\
Iowa & 1.78 & 1.68 & 1.92 & 0.06 & 1.79 \\
Indiana & 2.12 & 2.03 & 2.25 & 0.06 & 2.13 \\
Ohio & 2.34 & 2.27 & 2.46 & 0.04 & 2.34 \\
\hline
\end{tabular}

Source: Fiserv CSW Inc., OFHEO, and Bureau of Economic Analysis data.

a. States are listed in descending order according to their standard deviation of home prices.

most volatile. Since the equations are in reduced form, the individual coefficients are plagued by simultaneity. For example, housing starts may proxy for supply restrictions. That is, where supply is restricted, starts may be low, pushing up prices. On the other hand, builders clearly respond to higher prices by building more. Similarly, the change in employment could have a positive impact on home prices as a proxy for demand. On the other hand, rising home prices have been shown to have a negative effect on employment growth in a state by making it difficult to attract employees to a region with high housing costs. ${ }^{12}$ In the equations in which the change in price is the dependent variable (top panel of the table), the number of housing starts has a positive and significant coefficient in seven of the eight states. However, in equations in which

12. Case (1986). 
Figure 2. Ratio of Home Prices to Personal Income per Capita in Selected States, 1985-2002

\section{California}

Ratio

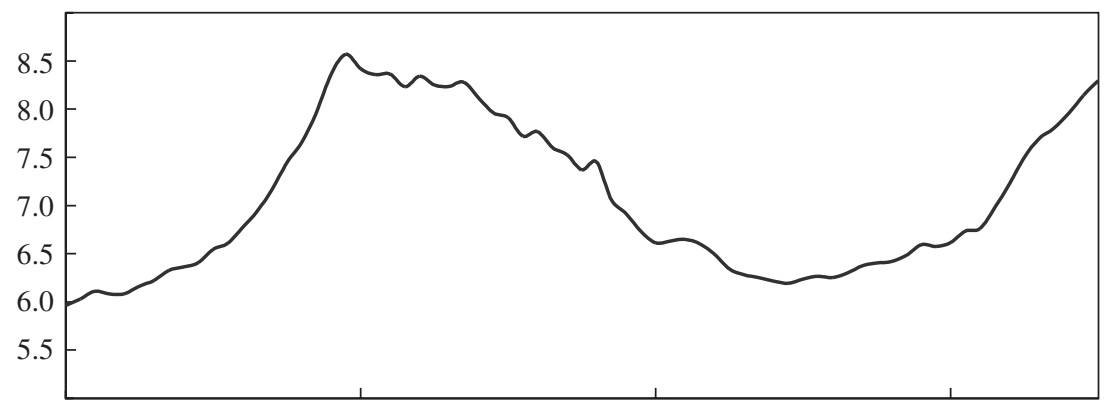

Massachusetts

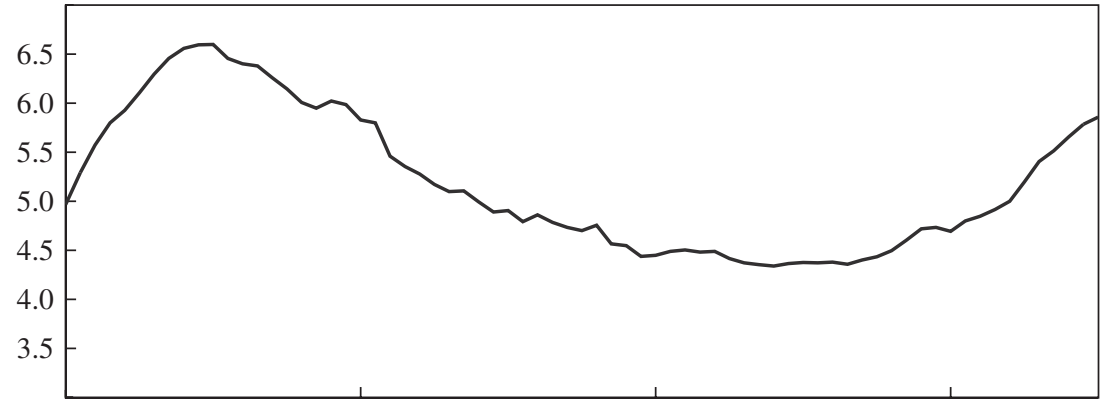

Wisconsin

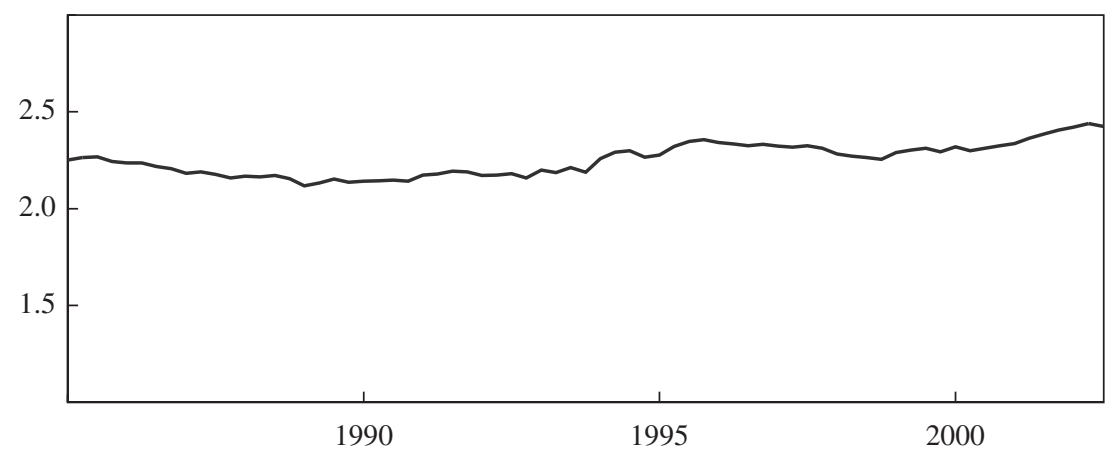

Source: Authors' calculations using data from Bureau of Economic Analysis and Office of Federal Housing Enterprise Oversight. 
Table 3. Regressions of Home Prices on Fundamentals in the Most Price-Volatile States ${ }^{\text {a }}$

$\begin{array}{lccccccc}\begin{array}{l}\text { Independent } \\ \text { variable }\end{array} & \text { New } & \text { Rhode } & \text { Massa- } & \text { New } & \text { New } \\ \text { bawaii } & \text { Connecticut } & \text { Hampshire } & \text { California } & \text { Island } & \text { chusetts } & \text { Jersey } & \text { York }\end{array}$

Change in population (percent)

Dependent variable: quarterly change in home prices, 1985:1-2002:3

Change in employment (percent)

Mortgage rate (percent a year)

Unemployment rate (percent)

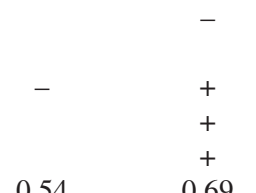

$$
+
$$

Housing starts

Income per capita

Adjusted $R^{2}$

Change in population (percent)

Change in employment (percent)

Mortgage rate (percent a year)

Unemployment rate (percent)

Housing starts

Income per capita

Adjusted $R^{2}$

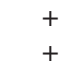

0.71

Dependent variable: quarterly level of home prices 1985:1-1999:4

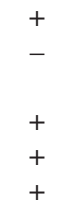

0.97

0.49

0.48

$+$

$-$

Dependent variable: quarterly level of home prices 1985:1-1999:4

One-year change in population (percent)

One-year change in employment

$$
\text { (percent) }
$$

Ratio of income per capita to

annual mortgage payment

Unemployment rate (percent)

Income per capita

Adjusted $R^{2}$

\section{$+$}

$+$

$-$

$+$

Source: Authors' regressions.

a. A plus sign indicates that the coefficient on the variable is positive and statistically significant at the 5 percent level, and a minus sign indicates that it is negative and significant at the 5 percent level. b. Independent variables use quarterly data except where stated otherwise. 
the price level is the dependent variable (middle panel), which are estimated over a shorter time horizon (1985:2 through 1999:4), housing starts has a significant but negative coefficient in five of the eight states. Income has a significant and positive coefficient in twenty of the twentyfour equations presented. The change in employment had a significant and negative effect in fourteen of the twenty-four equations. Unemployment has a significant and negative coefficient in the price level equations in five of the eight states.

Of interest is the fact that the mortgage rate has an insignificant coefficient in all but one of the regressions presented. This again could be the result of simultaneity: low rates stimulate the housing market, but low rates may be caused by Federal Reserve easing in response to a weak economy and housing market.

Including the ratio of income to mortgage payment in the regression allows us to take account of the wide swings in interest rates over this period. During 2000-02, the combination of low interest rates and high incomes made housing more affordable. Although this variable had a positive and significant sign in the equations run on all quarters in twenty-one states, it was significant and positive only in New York among the eight states with a high variance of income to home price.

To look more closely at the strength of the housing sector since the stock market crash of 2000-01 and the recession of 2001, we used the results from the price level equation estimated with 1985:2-1999:4 data, described above, to forecast the level of home prices for the period from 2000:1 through 2002:3. We did the same exercise with two sets of regressions described in the bottom two panels of table 3 .

The results from the middle panel of table 3 are presented in figure 3 . In all of the eight states except Hawaii, the fundamentals significantly underforecast the actual behavior of home prices since 1999. Diagrams constructed from the results of the bottom panel of table 3 look exactly the same.

To conclude this section, we find that income alone explains patterns of home price changes since 1985 in all but eight states. In these states the addition of other fundamental variables adds explanatory power, but the pattern of smoothly rising and falling price-to-income ratios and the consistent pattern of underforecasting of home prices during 2000-02 mean that we cannot reject the hypothesis that a bubble exists in these states. For further evidence we turn to our survey. 
Figure 3. Actual and Predicted Housing Prices, Selected States, 1985-2003

Price (current dollars)
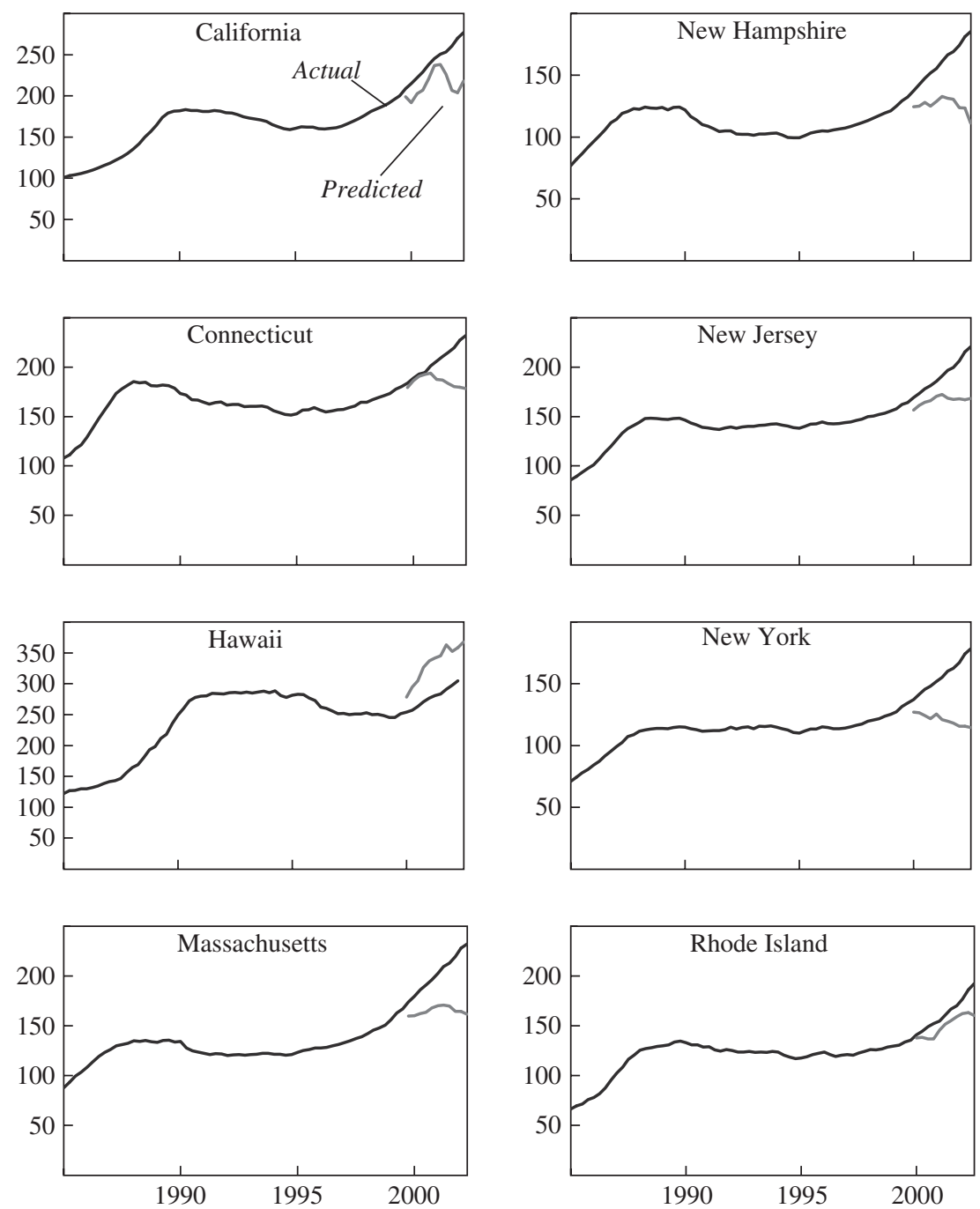

Source: Authors' calculations and data from OFHEO. 


\section{The 1988 Survey}

In our 1988 paper we presented the results of a survey of a sample of 2,000 households who bought homes in May 1988 in four markets: Orange County, California (suburban Los Angeles); Alameda County, California (suburban San Francisco); Middlesex County, Massachusetts (suburban Boston); and Milwaukee County, Wisconsin. ${ }^{13}$ The four locations were chosen to represent hot (California), cooling (Boston), and steady (Milwaukee) markets. The survey was inspired in part by an article on page 1 of the June 1, 1988, Wall Street Journal, which described the current "frenzy in California's big single family home market" and included colorful stories of angst and activity in the housing market there. ${ }^{14}$ We wanted to find out what was going on in California and compare it with other places in a systematic way.

The results of that survey provide strong evidence for some parameters of a theory that a housing bubble did exist in 1988: that buyers were influenced by an investment motive, that they had strong expectations about future price changes in their housing markets, and that they perceived little risk. Responses to a number of questions revealed that emotion and casual word of mouth played a significant role in home purchase decisions. In addition, there was no agreement among buyers about the causes of recent home price movements and no cogent analysis of the fundamentals.

One additional finding in our 1988 paper lends support to an important stylized fact about the U.S. housing market that has not been well documented in the literature, namely, that home prices are sticky downward. That is, when excess supply occurs, prices do not immediately fall to clear the market. Rather, sellers have reservation prices below which they tend not to sell. This tendency not to accept price declines is connected with a belief that prices never do decline, and with some of the parameters of thinking that underlie a housing bubble.

13. Case and Shiller (1988).

14. A. Nomani, Sr., "Nesting Fever: Buyers' Panic Sweeps California's Big Market in One-Family Homes," Wall Street Journal, June 1, 1988, p. 1. 


\section{Homebuyer Behavior in Four Metropolitan Areas, 1988 and 2003}

Before we present the results of a virtually identical survey done in 2003, we describe home price behavior in the four survey areas. Although the timing was not identical, Los Angeles, San Francisco, and Boston have experienced two boom cycles and a bust in housing prices over the last twenty years. Table 4 describes the timing and the extent of these cycles, which are also shown in nominal terms in figure 4.

The first boom in California was similar in Los Angeles and San Francisco. Prices in both metropolitan areas peaked in the second quarter of 1990 after a 125 percent nominal (55 percent real) run-up, which began slowly, gradually accelerated into 1988, and then slowed as it approached the peak. The first boom in Boston was also similar, but it accelerated earlier and actually peaked in the third quarter of 1988 after a 143 percent nominal (more than 100 percent real) increase.

The bust that followed was most severe and longest lived in Los Angeles, where prices dropped 29 percent in nominal terms ( 40 percent in real terms) from the peak to a trough in the first quarter of 1996. Prices in San Francisco dropped only 14 percent (20 percent real) from the 1990 peak and began rising again in the first quarter of 1993, three years earlier than in Los Angeles. Boston was on the mend two years earlier than that.

All three metropolitan areas have seen a prolonged boom ever since, although San Francisco has shown some volatility since mid-2002. Home prices during this boom rose 129 percent in nominal terms in San Francisco, 94 percent in Los Angeles, and 126 percent in Boston, despite very low overall inflation. At the time participants in the second survey sample were buying their homes, prices were still rising in all four metropolitan areas.

The price index for Milwaukee could not be more different. It shows a very steady climb at a rate of 5.6 percent annually, essentially the same rate of growth as income per capita. Interestingly, over the entire cycle, Milwaukee did about as well as Los Angeles, but not as well as Boston or San Francisco. Home prices in Boston increased more than fivefold in nominal terms over the cycle, while prices in San Francisco quadrupled and prices in both Milwaukee and Los Angeles tripled.

Three of the four metropolitan areas-Los Angeles, San Francisco, and Boston-show pronounced cycles. These three might be called glamour 
Table 4. Change in Average Home Price in Survey Cities during Boom and Bust, 1982-2003

Percent

\begin{tabular}{lcccc}
\hline Period & Los Angeles & San Francisco & Boston & Milwaukee \\
\hline 1982-peak & +128 & +126 & +143 & $\ldots{ }^{\mathrm{b}}$ \\
Peak quarter & $1990: 2$ & $1990: 2$ & $1988: 3$ & \\
Peak to trough & -29 & -14 & -16 & $\ldots$ \\
Trough quarter & $1996: 1$ & $1993: 1$ & $1991: 1$ & \\
Trough to peak & +94 & +129 & +126 & $\ldots$ \\
Peak quarter & $2003: 1$ & $2002: 3$ & $2003: 1$ & \\
Whole period & +214 & +325 & +419 & +213 \\
At annual rate & 5.6 & 7.1 & 8.2 & 5.6 \\
\hline
\end{tabular}

Source: Fiserv CSW Inc. repeat-sales indexes.

a. Data cover the period 1982:1-2003:1.

b. Home prices displayed no clear peak or trough during the period.

cities, in that they are the home of either international celebrities, or the entertainment industry, or world-class universities, or high-technology industries, and the prices of homes in these metropolitan areas are high as well as volatile. ${ }^{15}$

Table 5 looks at the latest boom cycle in a bit more detail. Using the state data described in the earlier section, the table makes two points. First, in all three states, home price increases outpaced income growth. (Note that the price increases are not as great as in the metropolitan area data because the indexes are for the entire state.) All three states had increases in their ratios of home price to annual income, but the changes were dramatically larger in the boom-and-bust states.

After peaking at nearly 10 percent in early 1995, the thirty-year fixed rate dropped below 7 percent by mid-1999. During 2000 rates spiked back to 8.5 percent but then fell steadily from mid-2000 until 2003, when they briefly went below 5 percent.

15. Differences in glamour across cities is a sensitive topic, but one that is nonetheless very real and ought to be taken note of here. Some of our respondents were very opinionated about these differences. One Milwaukee respondent wrote on the questionnaire: "I was laid off and forced to expand my job search nationwide. I did not want to leave Chicago and certainly did not want to relocate to Milwaukee, a second rate city with high unemployment. ... However, the upside is that the housing prices in Chicago are so much higher than Milwaukee County and I was able to sell my tiny Cape Cod for a beautiful 4 bedroom historic house on a prime residential street." 
Figure 4. Case-Shiller Home Price Index, Selected Metropolitan Areas, 1982-2003 ${ }^{\text {a }}$

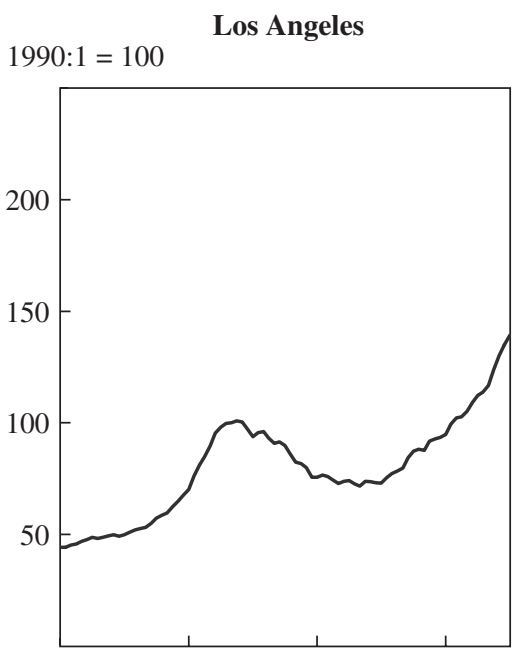

San Francisco

Boston
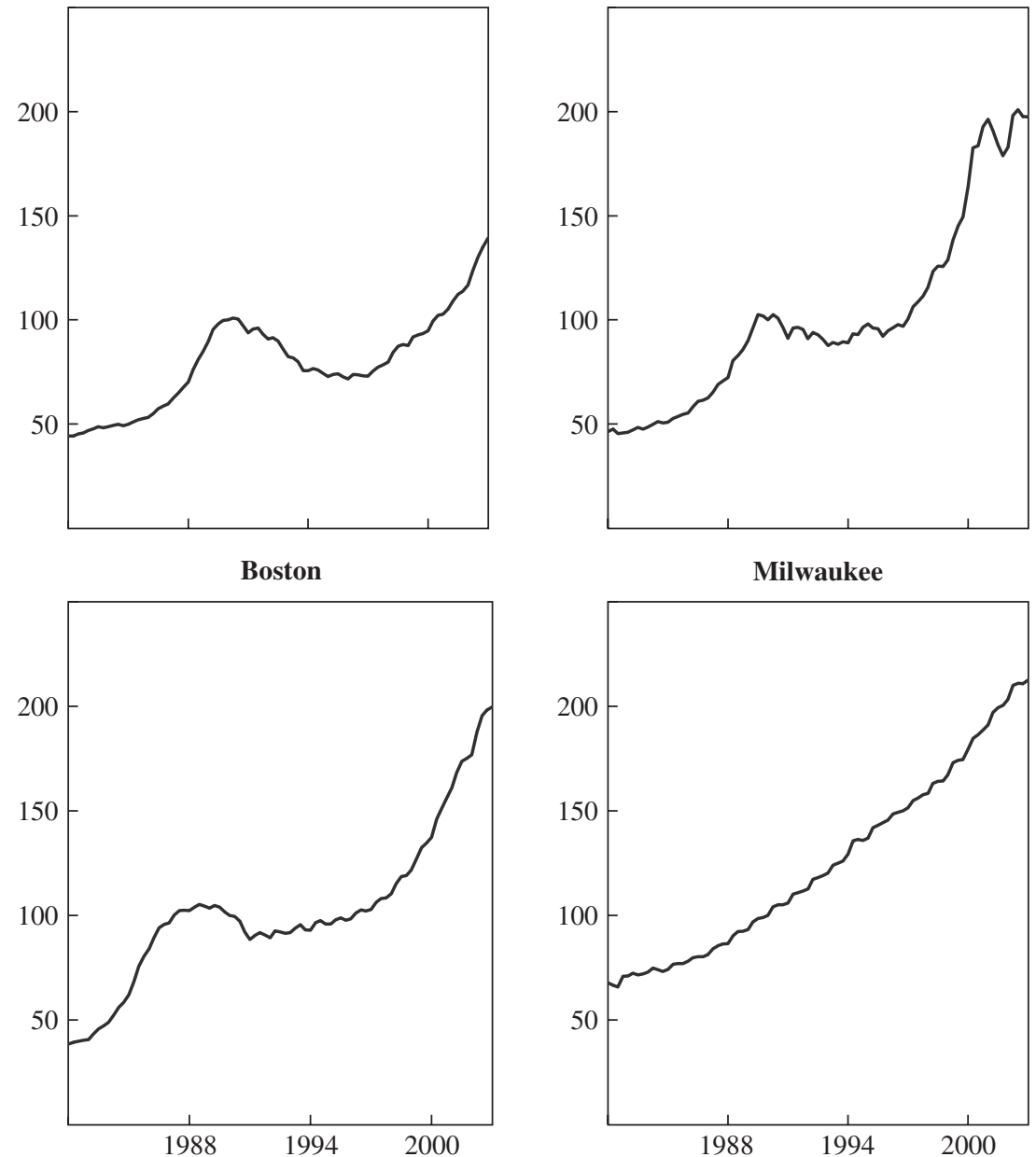

Milwaukee

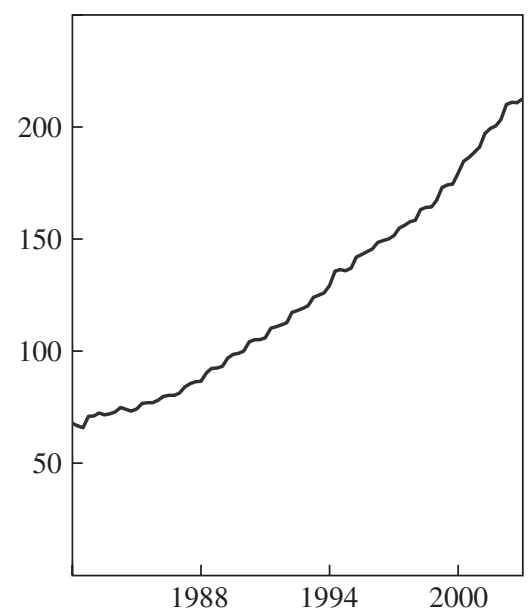

Source: Fiserv CSW, Inc.

a. Quarterly data. 
Table 5. Home Prices, Personal Income, and Mortgage Payments, Selected States, 1995 and 2002

Current dollars except where stated otherwise

\begin{tabular}{lccc}
\hline Measure & California & Massachusetts & Wisconsin \\
\hline Home prices & & & \\
1995: & 158,954 & 121,091 & 50,557 \\
2002:3 & 276,695 & 231,994 & 73,071 \\
Total change (percent) & +74 & +92 & +45 \\
At annual rate (percent) & 7.7 & 9.1 & 5.1 \\
Personal income per capita & & & \\
1995:1 & 24,044 & 27,224 & 22,203 \\
2002:3 & 33,362 & 39,605 & 30,138 \\
Total change (percent) & +39 & +45 & +35 \\
At annual rate (percent) & 4.5 & 5.1 & 4.1 \\
Ratio of home price to income per capita & & & \\
1995:1 & 6.61 & 4.45 & 2.28 \\
2002:3 & 8.29 & 5.86 & 2.42 \\
Annual mortgage payment & & & \\
1995:1 & & & 3,862 \\
2002:3 & 12,145 & 9,253 & 4,201 \\
Ratio of mortgage payment to income per capita & 0.51 & 13,338 & \\
1995:1 & 15,908 & & 0.17 \\
2002:3 & 0.47 & 0.34 & 0.14 \\
\hline Sources: Bureau of Economic Analysis, Economy.com, Fannie Mae, U.S. Bureau of the Census data adjusted using CSW or \\
blended repeat-sales indexes. \\
a. Assumes thirty-year fixed rate mortgage at 80 percent loan to value at annual interest rate of 8.8 percent (February 1995) or \\
6.0 percent (August 2002).
\end{tabular}

Table 5 also shows the effect of declining mortgage rates on the cash costs of buying a home. In 1995, at the beginning of the current run-up, the thirty-year fixed rate was 8.8 percent. It had fallen to 6 percent at the time the sample was drawn, keeping the monthly payment required to buy the median home from rising faster than income. The ratio of annual payment to income per capita actually fell in California and Wisconsin and stayed constant in Massachusetts. This fact adds weight to the argument that fundamental factors have an important effect on current home prices.

\section{Survey Method}

A random sample of 500 home sales was drawn from each of the same four counties as in our 1988 survey, and so we can make comparisons 
with these earlier results.We also used the very same questionnaire as in our 1988 survey, adding only several new questions at the end so that there was no change in the context of any questions. The accompanying letters were essentially similar to those of 1988 .

Survey methods followed guidelines outlined elsewhere. ${ }^{16}$ Ordinary mail was used because we judged that the use of e-mail was still not widespread enough to produce a representative sample. The questionnaire was ten pages long and included questions on a number of topics. The focus was on the homebuyers' expectations, understandings of the market situation, and behavior. The questionnaire encouraged respondents to "write comments anywhere on the questionnaire," and their comments were indeed helpful to us in interpreting the significance of the answers.

During the first survey, in 1988, two of the four markets were booming (the California counties), one market was at its peak and showing excess supply (Boston), and one was drifting (Milwaukee). This time three of the four markets were in remarkable booms, and Milwaukee again served as a control city, where no real boom was taking place.

The survey was sent to 2,000 persons who had bought homes between March and August 2002. These dates fall just before the peak in media usage of the term "housing bubble" in October 2002. Questionnaires with personalized letters to the respondents were mailed in January 2003, a reminder postcard was sent in February, and replacement questionnaires with personalized letters were again sent to those who had not responded in March. These dates were just after the peak in media use of the term "housing bubble." Thus we managed to get our questionnaire survey out at a time when attention to the possibility of a housing bubble must have been close to its maximum. Our respondents had the opportunity to participate in the real estate market at a time of intense public attention to the possibility of a bubble and had the opportunity to read and think about this experience for some months afterward. This is what we wanted to do, since our purpose is to gauge human behavior during a purported bubble.

Just under 700 questionnaires were returned completed and usable in the 2003 survey, for a somewhat lower response rate than in the 1988 survey. Response rates for each county are given in table 6 .

At the time of the 2003 survey, the economy was recovering from the recession that had ended in November 2001, but the recovery was slow,

16. Dillman (1978). 
Table 6. Survey Sample Sizes and Response Rates in 1988 and 2003

\begin{tabular}{|c|c|c|c|c|c|c|}
\hline \multirow[b]{2}{*}{ Metropolitan area } & \multicolumn{2}{|c|}{ Sample size } & \multicolumn{2}{|c|}{$\begin{array}{l}\text { Returns } \\
\text { tabulated }\end{array}$} & \multicolumn{2}{|c|}{$\begin{array}{l}\text { Response rate } \\
\text { (percent) }\end{array}$} \\
\hline & 1988 & 2003 & 1988 & 2003 & 1988 & 2003 \\
\hline Los Angeles & 500 & 500 & 241 & 143 & 48.2 & 28.6 \\
\hline San Francisco & 530 & 500 & 199 & 164 & 37.5 & 32.8 \\
\hline Boston & 500 & 500 & 200 & 203 & 40.0 & 40.6 \\
\hline Milwaukee & 500 & 500 & 246 & 187 & 49.2 & 37.4 \\
\hline Total & 2,030 & 2,000 & 886 & 697 & 43.9 & 34.9 \\
\hline
\end{tabular}

Source: Authors' survey described in the text.

and the National Bureau of Economic Research had not yet announced that the recession was over. In contrast, at the time of our 1988 survey, there had been no recession for several years. In addition, the Federal Reserve had reduced interest rates to historic lows at the time the buyers in our 2003 survey were signing purchase and sale agreements. In 1988, in contrast, interest rates were on the rise.

Table 7 describes the sample. A substantial majority of buyers were buying as a primary residence, and only a small minority were buying to rent. First-time buyers were a majority of the sample in Milwaukee. The lowest percentage of first-time buyers was in Los Angeles. We were surprised to see that, in the 2003 survey, more than 90 percent of the homes purchased in all four markets were single-family homes, a much larger share than in the 1988 survey. We have no explanation as yet for this.

Table 7. Characteristics of Respondents' Home Purchases

Percent of responses except where stated otherwise

\begin{tabular}{|c|c|c|c|c|c|c|c|c|}
\hline \multirow[b]{2}{*}{ Description } & \multicolumn{2}{|c|}{ Los Angeles } & \multicolumn{2}{|c|}{$\begin{array}{c}\text { San } \\
\text { Francisco }\end{array}$} & \multicolumn{2}{|c|}{ Boston } & \multicolumn{2}{|c|}{ Milwaukee } \\
\hline & 1988 & 2003 & 1988 & 2003 & 1988 & 2003 & 1988 & 2003 \\
\hline Single-family home & 70.0 & 95.2 & 55.9 & 96.4 & 39.7 & 97.5 & 71.1 & 91.6 \\
\hline First-time purchase & 35.8 & 31.7 & 36.2 & 46.0 & 51.5 & 41.6 & 56.9 & 53.1 \\
\hline $\begin{array}{l}\text { Bought as primary } \\
\text { residence }\end{array}$ & 88.4 & 95.6 & 72.7 & 93.3 & 92.0 & 97.1 & 88.2 & 90.0 \\
\hline Bought to rent to others & 3.7 & 2.8 & 12.1 & 3.0 & 3.0 & 0.9 & 4.1 & 5.3 \\
\hline
\end{tabular}




\section{Survey Results}

The results of the 2003 survey, presented in tables 8 through 14, shed light on a number of aspects of homebuying behavior-including investment motivations and the expectation of further price rises, the amount of local excitement and discussion about real estate, the sense of urgency in buying a home, adherence to simplistic theories about housing markets, the occurrence of sales above asking prices, and perceptions of risk - that suggest the presence or absence of a bubble in home prices.

\section{Housing as an Investment}

A tendency to view housing as an investment is a defining characteristic of a housing bubble. Expectations of future appreciation of the home are a motive for buying that deflects consideration from how much one is paying for housing services. That is what a bubble is all about: buying for the future price increases rather than simply for the pleasure of occupying the home. And it is this motive that is thought to lend instability to bubbles, a tendency to crash when the investment motive weakens.

Table 8 presents the responses to questions about housing as an investment. For the vast majority of buyers, either investment was "a major consideration" or they at least "in part" thought of their purchase as an investment. In Milwaukee and San Francisco investment was a major consideration for a majority of buyers. This tendency to view housing as an investment is similar to what it was in the boom period that we observed in our 1988 survey, although somewhat weaker. Far fewer of the homebuyers in 2003 said that they were buying "strictly for investment purposes." Thus conditions reported in 2003 would appear to be consistent with a bubble story, although less so than they were in 1988.

The apparent attractiveness of housing as an investment is further enhanced if the buyer perceives that the investment entails only very little risk. As table 8 also shows, in all cities in both 1988 and 2003, only a small percentage of buyers thought that housing involved a great deal of risk, although the fraction seeing a great deal of risk rose (perhaps not surprisingly) to a fairly high level (14.8 percent) in San Francisco in 2003. In three of the four cities (Milwaukee being the exception), there was more perception of risk in 2003 than there had been in 1988, which is what one 
Table 8. Survey Responses on Housing as an Investment, 1988 and 2003

Percent of responses except where stated otherwise

\begin{tabular}{|c|c|c|c|c|c|c|c|c|}
\hline \multirow[b]{2}{*}{ Question } & \multicolumn{2}{|c|}{ Los Angeles } & \multicolumn{2}{|c|}{$\begin{array}{c}\text { San } \\
\text { Francisco }\end{array}$} & \multicolumn{2}{|c|}{ Boston } & \multicolumn{2}{|c|}{ Milwaukee } \\
\hline & 1988 & 2003 & 1988 & 2003 & 1988 & 2003 & 1988 & 2003 \\
\hline \multicolumn{9}{|c|}{$\begin{array}{l}\text { In deciding to buy your property, did you think } \\
\text { of the purchase as an investment? }\end{array}$} \\
\hline $\begin{array}{l}\text { It was a major } \\
\text { consideration }\end{array}$ & 56.3 & 46.8 & 63.8 & 51.8 & 48.0 & 33.9 & 44.0 & 50.3 \\
\hline In part & 40.3 & 46.2 & 31.7 & 34.4 & 45.0 & 56.2 & 45.7 & 42.2 \\
\hline Not at all & 4.2 & 7.0 & 4.5 & 9.8 & 7.0 & 9.9 & 10.3 & 7.5 \\
\hline No. of responses & 238 & 143 & 199 & 164 & 200 & 203 & 243 & 187 \\
\hline \multicolumn{9}{|l|}{$\begin{array}{l}\text { Why did you buy the } \\
\text { home that you did? }\end{array}$} \\
\hline $\begin{array}{l}\text { Strictly for investment } \\
\text { purposes }\end{array}$ & 19.8 & 7.5 & 37.2 & 10.6 & 15.6 & 8.2 & 18.7 & 13.8 \\
\hline No. of responses & 238 & 142 & 199 & 164 & 199 & 203 & 246 & 187 \\
\hline \multicolumn{9}{|l|}{$\begin{array}{l}\text { Buying a home in [city] } \\
\text { today involves }\end{array}$} \\
\hline A great deal of risk & 3.4 & 7.9 & 4.2 & 14.8 & 5.1 & 7.8 & 5.9 & 4.3 \\
\hline Some risk & 33.3 & 47.5 & 40.1 & 51.9 & 57.9 & 62.5 & 64.6 & 57.3 \\
\hline Little or no risk & 63.3 & 44.6 & 55.7 & 33.3 & 37.1 & 29.6 & 29.5 & 38.4 \\
\hline No. of responses & 237 & 143 & 192 & 164 & 197 & 203 & 237 & 187 \\
\hline
\end{tabular}

would expect given all the media attention to bubbles in 2003. Even so, the perception of risk of price decline is small: one may say that homebuyers did not perceive themselves to be in a bubble.

\section{Exaggerated Expectations, Excitement, and Word of Mouth}

Table 9 gets to the meat of the housing bubble issue: the role of price expectations, the emotional charge, and the extent of talk about real estate. Expectations about the future price performance of homes were high in both 1988 and 2003. In both of these housing booms, roughly 90 percent or more of respondents expected an increase in home prices over the next several years, and the average expected increase over the 
Table 9. Survey Responses on Price Expectations, Sense of Excitement, and Talk, 1988 and 2003

Percent of responses except where stated otherwise

\begin{tabular}{|c|c|c|c|c|c|c|c|c|}
\hline \multirow[b]{2}{*}{ Question } & \multicolumn{2}{|c|}{ Los Angeles } & \multicolumn{2}{|c|}{$\begin{array}{c}\text { San } \\
\text { Francisco }\end{array}$} & \multicolumn{2}{|c|}{ Boston } & \multicolumn{2}{|c|}{ Milwaukee } \\
\hline & 1988 & 2003 & 1988 & 2003 & 1988 & 2003 & 1988 & 2003 \\
\hline \multicolumn{9}{|c|}{$\begin{array}{l}\text { Do you think that housing prices in the [city] area } \\
\text { will increase or decrease over the next several years? }\end{array}$} \\
\hline Increase & 98.3 & 89.7 & 99.0 & 90.5 & 90.2 & 83.1 & 87.1 & 95.2 \\
\hline Decrease & 1.7 & 10.3 & 1.0 & 9.5 & 9.8 & 16.9 & 12.9 & 4.8 \\
\hline No. of responses & 240 & 145 & 199 & 158 & 194 & 201 & 233 & 187 \\
\hline
\end{tabular}

How much of a change do you expect there to be in the value of your home over the next 12 months?

$\begin{array}{lrrrrrrrr}\begin{array}{l}\text { Mean response } \\ \quad \text { (percent) }\end{array} & 15.3 & 10.5 & 13.5 & 9.8 & 7.4 & 7.2 & 6.1 & 8.9 \\ \text { Standard error } & 0.8 & 0.6 & 0.6 & 0.6 & 0.6 & 0.4 & 0.5 & 1.0 \\ \text { No. of responses } & 217 & 139 & 185 & 147 & 176 & 179 & 217 & 160\end{array}$

On average over the next 10 years, how much do you expect the value of your property to change each year?

$\begin{array}{lrrrrrrrr}\begin{array}{l}\text { Mean response } \\ \quad \text { percent) }\end{array} & 14.3 & 13.1 & 14.8 & 15.7 & 8.7 & 14.6 & 7.3 & 11.7 \\ \begin{array}{l}\text { Standard error } \\ \text { No. of responses }\end{array} & 1.2 & 1.2 & 1.4 & 1.8 & 0.6 & 1.8 & 0.5 & 1.3 \\ & 208 & 137 & 181 & 152 & 177 & 186 & 211 & 169\end{array}$

Which of the following best describes the trend in home prices in the [city] area since January 1988 ?

$\begin{array}{lrrrrrrrr}\text { Rising rapidly } & 90.8 & 76.2 & 83.7 & 28.6 & 3.0 & 29.6 & 8.7 & 33.0 \\ \text { Rising slowly } & 8.8 & 22.4 & 12.8 & 51.0 & 34.3 & 49.2 & 53.0 & 57.3 \\ \text { Not changing } & 0.4 & 1.4 & 3.1 & 14.3 & 37.4 & 12.6 & 23.9 & 8.6 \\ \text { Falling slowly } & 0.0 & 0.0 & 0.5 & 6.2 & 22.2 & 8.5 & 11.7 & 1.1 \\ \text { Falling rapidly } & 0.0 & 0.0 & 0.0 & 0.0 & 3.0 & 0.0 & 2.6 & 0.0 \\ \text { No. of responses } & 239 & 143 & 196 & 161 & 198 & 199 & 230 & 185\end{array}$

It's a good time to buy because housing prices are likely to rise in the future.

$\begin{array}{lrrrrrrrc}\text { Agree } & 93.2 & 77.0 & 95.0 & 82.1 & 77.8 & 66.1 & 84.8 & 87.0 \\ \text { Disagree } & 6.8 & 23.0 & 5.0 & 17.9 & 22.2 & 33.9 & 15.2 & 13.0 \\ \text { No. of responses } & 206 & 126 & 180 & 145 & 171 & 174 & 210 & 161\end{array}$

Housing prices are booming. Unless I buy now, I won't be able to afford a home later.

$\begin{array}{lcccccccc}\text { Agree } & 79.5 & 48.8 & 68.9 & 59.7 & 40.8 & 37.1 & 27.8 & 36.4 \\ \text { Disagree } & 20.5 & 51.2 & 31.1 & 40.3 & 59.2 & 62.9 & 72.2 & 63.6 \\ \text { No. of responses } & 200 & 124 & 167 & 134 & 169 & 175 & 194 & 154 \\ & & & & & & & & \\ & & & & & & & & \end{array}$


Table 9. Survey Responses on Price Expectations, Sense of Excitement, and Talk, 1988 and 2003 (continued)

Percent of responses except where stated otherwise

\begin{tabular}{|c|c|c|c|c|c|c|c|c|}
\hline \multirow[b]{2}{*}{ Question } & \multicolumn{2}{|c|}{ Los Angeles } & \multicolumn{2}{|c|}{$\begin{array}{c}\text { San } \\
\text { Francisco }\end{array}$} & \multicolumn{2}{|c|}{ Boston } & \multicolumn{2}{|c|}{ Milwaukee } \\
\hline & 1988 & 2003 & 1988 & 2003 & 1988 & 2003 & 1988 & 2003 \\
\hline
\end{tabular}

There has been a good deal of excitement surrounding recent housing price changes. I sometimes think that I may have been influenced by it.

$\begin{array}{lcccccccc}\text { Yes } & 54.3 & 46.1 & 56.5 & 38.5 & 45.3 & 29.6 & 21.5 & 34.8 \\ \text { No } & 45.7 & 53.9 & 43.5 & 61.5 & 54.7 & 70.4 & 78.5 & 65.2 \\ \text { No. of responses } & 230 & 141 & 191 & 156 & 181 & 199 & 233 & 184\end{array}$

In conversations with friends and associates over the last few months, conditions in the housing market were discussed...

\begin{tabular}{lrrrrrrrr} 
Frequently & 52.9 & 32.9 & 49.7 & 37.4 & 30.3 & 31.0 & 20.0 & 27.6 \\
Sometimes & 38.2 & 50.3 & 39.0 & 43.6 & 55.1 & 53.7 & 50.2 & 40.5 \\
Seldom & 8.0 & 14.7 & 9.7 & 17.2 & 12.1 & 14.3 & 25.1 & 28.1 \\
Never & 0.8 & 2.1 & 1.5 & 1.8 & 2.5 & 1.0 & 4.7 & 3.8 \\
No. of responses & 238 & 143 & 195 & 163 & 198 & 203 & 235 & 185 \\
\hline
\end{tabular}

Source: Authors' survey described in the text.

next twelve months was very high, even surpassing 9.8 percent in San Francisco in 2003. ${ }^{17}$

But it is the long-term (ten-year) expectations that are most striking. When asked what they thought would be the average rate of increase per year over the next ten years, respondents in Los Angeles gave an average reply of 13.1 percent (versus 14.3 percent in 1988); in San Francisco they were even more optimistic, at 15.7 percent (14.8 percent in 1988); in Boston the answer was 14.6 percent ( 8.7 percent in 1988); and in Milwaukee it was 11.7 percent (7.3 percent in 1988). Note that even a rate of increase of only 11.7 percent a year means a tripling of value in ten years. Thus, although the one-year expectations in the glamour cities were lower

17. In 2003 the median expected twelve-month price increases were 10 percent for Los Angeles, 7 percent for San Francisco, 5 percent for Boston, and 5 percent for Milwaukee. The lower values for the medians than for the corresponding means reflect the fact that the high expectations for future price increase were especially concentrated among a relatively few respondents." 
in 2003 than they had been in 1988, the ten-year expectations were even higher. ${ }^{18}$

Fewer respondents in 2003 said that it was a good time to buy a home because prices may be rising in the future, but at least two-thirds agreed with the statement in all four cities. Many thought not only that now was a good time to buy, but also that there was a risk that delay might mean not being able to afford a home later.

The number who admitted to being influenced by "excitement" about home prices was still high, close to 50 percent in Los Angeles, but lower than in 1988. The amount of talk was nearly as high as in 1988, and talk is an important indicator of a bubble, since word-of-mouth transmission of the excitement is a hallmark.

We conclude that these general indicators of the defining characteristics of bubbles were fairly strong in 2003. However, they were generally less strong than in 1988 in the glamour cities and stronger than in 1988 in Milwaukee.

\section{Simple (or Simplistic) Theories}

Table 10 shows results on respondents' agreement with a number of simple, popular theories or stories about speculative price movements that might influence how their interpretation of recent events translated into bubble expectations. Our survey results indicate that these simplistic theories are quite a powerful force and, moreover, a bit different in the glamour or bubble cities of Los Angeles, San Francisco, and Boston than in cities generally thought less exciting, like Milwaukee.

The most simplistic theory is one that we have often heard expressed in casual conversation: that desirable real estate just naturally appreciates rapidly. The theory expressed seems to confuse the level of prices with the rate of change. The most elementary economic theory would say that properties that people find most attractive will be highly priced, but not necessarily increasing more rapidly in price than other properties. We tried to gauge agreement with this theory by asking whether people agreed with the statement "Housing prices have boomed in [city] because

18. The median ten-year expectations were 8 percent in Los Angeles, 7 percent in San Francisco, 5 percent in Boston, and 5 percent in Milwaukee; once again the medians show less strikingly high expectations. 
Table 10. Survey Responses on Homebuyers' Agreement with Simple Theories of Housing Prices, 1988 and 2003

Percent of responses except where stated otherwise

\begin{tabular}{|c|c|c|c|c|c|c|c|c|}
\hline \multirow[b]{2}{*}{ Question } & \multicolumn{2}{|c|}{ Los Angeles } & \multicolumn{2}{|c|}{ San Francisco } & \multicolumn{2}{|c|}{ Boston } & \multicolumn{2}{|c|}{ Milwaukee } \\
\hline & 1988 & 2003 & 1988 & 2003 & 1988 & 2003 & 1988 & 2003 \\
\hline \multicolumn{9}{|c|}{ Housing prices have boomed in [city] because lots of people want to live here. } \\
\hline Agree & 98.6 & 93.8 & 93.3 & 89.1 & 69.6 & 77.8 & 16.1 & 23.0 \\
\hline Disagree & 1.4 & 6.2 & 6.7 & 10.9 & 30.4 & 22.2 & 83.9 & 77.0 \\
\hline No. of responses & 210 & 128 & 178 & 147 & 181 & 176 & 193 & 148 \\
\hline \multicolumn{9}{|l|}{ The real problem in [city] is that there is just not enough land available. } \\
\hline Agree & 52.8 & 60.3 & 83.9 & 59.6 & 54.2 & 72.9 & 17.2 & 35.4 \\
\hline Disagree & 47.2 & 39.7 & 16.1 & 40.4 & 45.8 & 27.1 & 82.8 & 64.6 \\
\hline No. of responses & 197 & 121 & 174 & 141 & 168 & 177 & 192 & 158 \\
\hline \multicolumn{9}{|c|}{ When there is simply not enough housing available, price becomes unimportant. } \\
\hline Agree & 34.0 & 31.9 & 40.6 & 32.6 & 26.9 & 32 & 20.7 & 25.2 \\
\hline Disagree & 66.0 & 68.1 & 59.4 & 67.4 & 73.1 & 68 & 79.3 & 74.8 \\
\hline No. of responses & 197 & 116 & 165 & 141 & 171 & 172 & 193 & 151 \\
\hline \multicolumn{9}{|c|}{$\begin{array}{l}\text { In a hot real estate market, sellers often get more than one offer on the day they list the property. } \\
\text { Some are even over the asking price. There are also stories about people waiting in line to make } \\
\text { offers. Which is the best explanation? }\end{array}$} \\
\hline $\begin{array}{l}\text { There is panic buying and price becomes irrelevant. } \\
\text { Asking prices have adjusted slowly or sluggishly to increasing }\end{array}$ & 73.3 & 63.7 & 71.2 & 73.9 & 61.4 & 73.1 & 34.6 & 46.8 \\
\hline $\begin{array}{l}\text { Asking prices have adjusted slowly or sluggishly to increasing } \\
\text { demand. }\end{array}$ & 26.7 & 36.2 & 28.8 & 26.1 & 38.6 & 39.9 & 65.4 & 53.2 \\
\hline No. of responses & 210 & 135 & 177 & 153 & 176 & 197 & 211 & 173 \\
\hline \multicolumn{9}{|c|}{ Which of the following better describes your theory about recent trends in home prices in [city]? } \\
\hline It is a theory about the psychology of homebuyers and sellers. & 11.9 & 10.8 & 16.7 & 15.0 & 21.3 & 11.8 & 10.7 & 13.7 \\
\hline It is a theory about economic or demographic conditions such as & & & & & & & & \\
\hline population changes, changes in interest rates, or employment. & 88.1 & 89.2 & 83.3 & 85.0 & 78.7 & 88.2 & 89.3 & 86.3 \\
\hline No. of responses & 226 & 130 & 180 & 153 & 188 & 195 & 215 & 168 \\
\hline
\end{tabular}

Source: Authors' survey described in the text. 
lots of people want to live here." There was overwhelming agreement with this statement in all the glamour cities, but not in Milwaukee.

An even more outrageous fallacy that we detect in popular conversation about home prices is that "When there is simply not enough housing available, price becomes unimportant." To our respondents' credit, most did not agree with this statement. But from 20 to 40 percent did agree, particularly in the glamour cities.

Another fallacy we think we have detected is in the interpretation of prices closing above asking prices. Homeowners sometimes seem to think that this phenomenon is a sign of a crazy boom that suspends the economic laws of supply and demand. Indeed, most homebuyers in the glamour cities thought that at such a time "there is panic buying and price becomes irrelevant."

These results do not firmly prove that people are guilty of economic fallacies, because the questions admit of alternative interpretations, and people were probably not focusing clearly on their exact wording. However, we do believe that the strong agreement with some of these statements is at least suggestive of such fallacies. We believe that there is a sort of knee-jerk reaction to stories about boom markets in real estate that does not accord with economic theory, but that does affect the prices people are willing to pay for their homes. We leave clearer proof that people adhere to such fallacies to further work. A closer study of such popular fallacies is difficult to carry out, for if we draw out the fallacy clearly enough to reveal their belief in it to our satisfaction, respondents may be educated out of the fallacy by the very questioning intended to reveal it.

All these theories about panic buying and the irrelevance of price do not, however, indicate that people generally believe that markets are driven by psychology. The results of the last question in table 10 show that people generally do not believe that markets are driven primarily by psychology, even in a booming real estate market. We interpret this as further confirming our general conclusion that most homeowners do not perceive themselves to be in a bubble even at the height of a bubble.

\section{Popular Themes in Interpreting Recent Price Movements}

We have documented that people talked a lot about the housing market both in 1988 and in 2003. What is it that they are likely to have talked 
about? We need to know the news stories that are on their mind if we are to understand the origins of the purported housing bubble.

Table 11 shows some results from two open-ended questions that were put on the questionnaire, along with a space for the respondent to write in answers in his or her own words. Responses to these questions are especially interesting because they elicit themes that are already on the minds of respondents, rather than putting words in their mouths.

One would perhaps not expect any one theme to dominate in answers to such questions, since people are so different and such broad questions allow so many different interpretations. But we do see what appears to be a dominating theme both in 1988 and in 2003, namely, interest rates. Clearly, interest rates have fallen substantially and have contributed to the run-up in prices since 1995, at least in the cities where, in our regressions, the interest rate variable was significant. Although, according to basic economic theory, interest rates should be more important in regions where the elasticity of supply of housing is relatively low or the likely growth of future demand relatively high, there is little evidence of this effect in state-by-state regressions.

Many of the answers to these questions are disappointing. Typically the answers read like random draws from the business section of the newspaper, or else the respondents refer to casual observations that one might make just driving around town. Respondents presented no quantitative evidence and made no reference to professional forecasts. One should not be surprised at this, however. After all, the single-family home market is a market of amateurs, generally with no economic training.

Once more we see evidence that in neither period did many homebuyers perceive themselves to be in a housing bubble. References to market psychology were quite rare.

\section{Relation of Investment Demand in 2003 to the}

Stock Market Boom and Bust

The appearance of the real estate bubble right after the stock market drop has lent support to the notion that the two are somehow connected. One popular theory is that the stock market drop was followed by investor disgust with the stock market and a "flight to quality," as people sought safer investments in real assets like homes. There has been a lot of discussion about people shifting their assets toward housing because 
Table 11. Survey Responses: Popular Themes Mentioned in Interpreting Recent Housing Price Changes, 1988 and 2003

Percent of responses ${ }^{\mathrm{a}}$

\begin{tabular}{|c|c|c|c|c|c|c|c|c|}
\hline \multirow[b]{2}{*}{ Question } & \multicolumn{2}{|c|}{ Los Angeles } & \multicolumn{2}{|c|}{$\begin{array}{c}\text { San } \\
\text { Francisco }\end{array}$} & \multicolumn{2}{|c|}{ Boston } & \multicolumn{2}{|c|}{ Milwaukee } \\
\hline & 1988 & 2003 & 1988 & 2003 & 1988 & 2003 & 1988 & 2003 \\
\hline \multicolumn{9}{|l|}{ National factors } \\
\hline Interest rate changes & 32 & 33 & 40 & 10 & 25 & 20 & 27 & 39 \\
\hline Stock market crash & 2 & 4 & 2 & 11 & 25 & 13 & 2 & 8 \\
\hline September 11, 2001 & & 6 & & 9 & & 16 & & 7 \\
\hline Iraq war 2003 & & 2 & & 4 & & 2 & & 3 \\
\hline Dot-com bust & & 2 & & 21 & & 4 & & 0 \\
\hline $\begin{array}{l}\text { Corporate scandals, } \\
\text { loss of confidence }\end{array}$ & & 0 & & 1 & & 0 & & 0 \\
\hline Poor or slow economy & & 5 & & 24 & & 34 & & 15 \\
\hline \multicolumn{9}{|l|}{ Regional factors } \\
\hline $\begin{array}{l}\text { Region is a good place } \\
\text { to live }\end{array}$ & 17 & 13 & 18 & 8 & 6 & 5 & 2 & 3 \\
\hline $\begin{array}{l}\text { Immigration or } \\
\text { population change }\end{array}$ & 20 & 8 & 8 & 7 & 11 & 5 & 2 & 8 \\
\hline Asian investors & 3 & 0 & 27 & 0 & 0 & 0 & 0 & 0 \\
\hline Asian immigrants & 2 & 0 & 14 & 0 & 1 & 0 & 0 & 0 \\
\hline Income growth & 3 & 1 & 2 & 4 & 2 & 2 & 1 & 2 \\
\hline Anti-growth legislation & 11 & 0 & 3 & 0 & 0 & 1 & 0 & 0 \\
\hline Not enough land & 8 & 5 & 19 & 2 & 2 & 3 & 0 & 0 \\
\hline Local taxes & 3 & 0 & 0 & 0 & 4 & 0 & 10 & 4 \\
\hline $\begin{array}{l}\text { Increasing black } \\
\text { population }\end{array}$ & 0 & 0 & 0 & 0 & 0 & 0 & 7 & 0 \\
\hline Rental rates and vacancies & 0 & 1 & 3 & 0 & 7 & 3 & 2 & 0 \\
\hline Traffic congestion & 4 & 0 & 7 & 1 & 0 & 0 & 0 & 0 \\
\hline Local economy-general & 25 & 3 & 5 & 6 & 30 & 6 & 18 & 5 \\
\hline \multicolumn{9}{|l|}{ Other } \\
\hline $\begin{array}{l}\text { Psychology of the } \\
\text { housing markets }\end{array}$ & 5 & 2 & 7 & 2 & 18 & 1 & 1 & 1 \\
\hline Quantitative evidence $^{c}$ & 0 & 0 & 0 & 0 & 0 & 0 & 0 & 0 \\
\hline
\end{tabular}

Source: Authors' survey described in the text.

a. Percent of questionnaires that mentioned, in answer to either of two open-ended questions, the general subject indicated as determined by the authors' reading of their text answers. The questions were the following: "What do you think explains recent changes in home prices in [city]? What ultimately is behind what's going on?" and "Was there any event (or events) in the last two years that you think changed the trend in home prices?"

b. Any reference to panic, frenzy, greed, apathy, foolishness, excessive optimism, excessive pessimism, or other such factors was coded in this category.

c. The coder was asked to look for any reference at all to any numbers relevant to future supply or demand for housing or to any professional forecast of supply or demand. The numbers need not have been presented, so long as the respondent seemed to be referring to such numbers. 
the stock market has performed so poorly since 2000 . On the other hand, a falling stock market could have a negative wealth effect on home buying decisions. ${ }^{19}$

Table 12 presents the responses to three questions that we did not ask in 1988 but were added at the end of the questionnaire in 2003. Recall that the survey was virtually finished before the stock market rally ( 25 percent on the S\&P500) of March 11-July 8, 2003, and that the respondents had purchased their homes several months before.

The answers to the last question in table 12, about whether the experience with the stock market encouraged purchase of a home, show that for the vast majority of people in all four counties the performance of the stock market "had no effect on my decision to buy my house." However, one should not discard the notion that the stock market's behavior was at least partly responsible for the boom in the real estate market. Judging from their additional comments, it appears that some of the majority who said the stock market had no effect on the decision to buy a home said so only because they would have bought some home in any event, even if perhaps a smaller home. More significantly, many other respondents (roughly between a quarter and a third) said that the stock market's performance "encouraged" them to buy a home, whereas only a small percentage found it discouraging.

Immediately after this question we included an open-ended question, "Please explain your thinking here," followed by an open space. Although most left this space blank, the answers we did get were all over the map, as respondents apparently viewed the question as an opportunity to vent on any subject.

Some of the answers from those who said they were encouraged by the stock market did refer to the drop in the stock market after 2000 as a reason to buy a home now. Quoting a few of their answers verbatim will illustrate: "Housing costs continue to increase. Value of home investment to increase. Stock market not so promising." "Could be better investment than stock market." "I lost $\$ 400,000$ in my pension and personal stock portfolio-at least buying this big beautiful home I know it's a hard asset that would hold its value $\&$ appreciate while it gives me great enjoyment." "Money that we had saved for a house was starting to become a loss in the market." "I have only made money in real estate and lost a lot in the stock

19. See Case, Quigley, and Shiller (2001). 
Table 12. Survey Responses on Real Estate versus Stock Market Investment, 2003

Percent of responses except where stated otherwise

\begin{tabular}{|c|c|c|c|c|}
\hline Question & Los Angeles & $\begin{array}{l}\text { San } \\
\text { Francisco }\end{array}$ & Boston & Milwaukee \\
\hline \multicolumn{5}{|c|}{ Do you agree with the following statement: } \\
\hline \multicolumn{5}{|c|}{$\begin{array}{l}\text { "Real estate is the best investment for long-term holders, } \\
\text { who can just buy and hold through the ups and downs } \\
\text { of the market"? }\end{array}$} \\
\hline Strongly agree & 53.7 & 50.6 & 36.7 & 31.3 \\
\hline Somewhat agree & 33.1 & 39.5 & 48.5 & 45.9 \\
\hline Neutral & 10.3 & 6.7 & 9.3 & 11.3 \\
\hline Somewhat disagree & 2.7 & 2.4 & 4.9 & 9.1 \\
\hline Strongly disagree & 0.0 & 0.6 & 0.4 & 2.1 \\
\hline No. of responses & 145 & 162 & 204 & 185 \\
\hline \multicolumn{5}{|c|}{$\begin{array}{l}\text { Do you agree with the following statement: "The stock } \\
\text { market is the best investment for long-term holders, } \\
\text { who can just buy and hold through the ups and } \\
\text { downs of the market"? }\end{array}$} \\
\hline Strongly agree & 8.2 & 8.0 & 14.7 & 14.9 \\
\hline Somewhat agree & 32.4 & 38.2 & 44.3 & 33.6 \\
\hline Neutral & 32.4 & 27.7 & 17.7 & 25.6 \\
\hline Somewhat disagree & 20.0 & 16.0 & 15.2 & 20.3 \\
\hline Strongly disagree & 6.8 & 9.8 & 7.8 & 5.3 \\
\hline No. of responses & 145 & 162 & 203 & 187 \\
\hline \multicolumn{5}{|l|}{$\begin{array}{l}\text { The experience with the stock market } \\
\text { in the past few years... }\end{array}$} \\
\hline $\begin{array}{l}\text { Much encouraged me to buy my } \\
\text { house }\end{array}$ & 13.9 & 15.5 & 14.3 & 9.1 \\
\hline $\begin{array}{l}\text { Somewhat encouraged me to buy } \\
\text { my house }\end{array}$ & 11.1 & 16.7 & 13.8 & 13.9 \\
\hline $\begin{array}{l}\text { Had no effect on my decision to } \\
\text { buy my house }\end{array}$ & 74.1 & 64.5 & 70.7 & 74.7 \\
\hline $\begin{array}{l}\text { Somewhat discouraged me from } \\
\text { buying my house }\end{array}$ & 0.0 & 2.4 & 0.9 & 2.1 \\
\hline $\begin{array}{l}\text { Much discouraged me from buying } \\
\text { my house }\end{array}$ & 0.6 & 0.6 & 0.0 & 0.0 \\
\hline No. of responses & 143 & 161 & 202 & 186 \\
\hline
\end{tabular}

Source: Authors' survey described in the text.

market." "The stock market at my age is not helping me. Short-term real estate is the strongest investment you can make short or long term." "Stock market went down. House market is still going up." "Renting is not cheap, stock is declining, this implies our total assets is [sic] not going anywhere." "The value of my condo had increased significantly compared to the gains to my portfolio. With interest rates low a new home seemed 
more likely to increase than a comparable investment in the stock market and brings tax \& quality of life benefits."

Some respondents referred to the increased volatility or other uncertainty in the stock market since 2000, rather than its changed level, as a reason to shift their portfolio: "It seemed that shifting some of our net worth to cash and homeownership was a wise move in the face of the market volatility in 2000-2002." "I'm buying the house for the long term. The house will probably depreciate in the next couple years, but it will certainly appreciate over $10+$ years. This is because it is a good house in a good community. This is information that I am confident of. In contrast, there is no confidence that I have full (or even good) information about the stock market (or that even my mutual fund managers have good information about the companies they invest in). So, I buy the house." "A house seems like a more solid investment than stocks. Less volatile."

Although this evidence is far from proof of a connection between the stock market and the housing market, we interpret it as confirming the notion that people got fed up with the stock market after the decline and high volatility following the 2000 peak and became more positive about real estate.

\section{Excess Demand and Upward Rigidity in Asking Prices}

In the boom cities, newspaper articles feature stories of homes that sold well above the asking price. We have already noted that it was an article in the Wall Street Journal referring to "frenzy in California's big single family home market" that inspired our original survey. In fact, such frenzy seems to be a fairly common occurrence in boom cities. As table 13 shows, quite a large number of people reported selling above the asking price in both the 1988 and 2003 surveys. An amazing 45 percent of respondents in San Francisco in the 2003 survey reported selling at above the asking price in 2002, well after the sharp decline in employment following the NASDAQ collapse, which began in 2000. Sellers in Los Angeles reported that about 20 percent of properties sold for more than the asking price, as did a slightly smaller share in Milwaukee, which had no boom.

Many of those who sold felt that if they had charged 5 or 10 percent more, the property would have sold just as quickly. This was the sense of 
Table 13. Survey Responses on Excess Demand and Upward Rigidity in Asking Prices, 1988 and 2003

Percent of responses except where stated otherwise

\begin{tabular}{|c|c|c|c|c|c|c|c|c|}
\hline \multirow[b]{2}{*}{ Question } & \multicolumn{2}{|c|}{ Los Angeles } & \multicolumn{2}{|c|}{$\begin{array}{c}\text { San } \\
\text { Francisco }\end{array}$} & \multicolumn{2}{|c|}{ Boston } & \multicolumn{2}{|c|}{ Milwaukee } \\
\hline & 1988 & 2003 & 1988 & 2003 & 1988 & 2003 & 1988 & 2003 \\
\hline \multicolumn{9}{|l|}{ Did you finally settle on the price that was... } \\
\hline Above the asking price? & 6.3 & 19.9 & 9.8 & 45.8 & 0.5 & 21.3 & 3.3 & 17.5 \\
\hline Equal to the asking price? & 38.0 & 50.4 & 26.8 & 27.5 & 23.5 & 59.1 & 22.7 & 52.4 \\
\hline Below the asking price? & 55.7 & 29.7 & 63.4 & 26.7 & 76.0 & 28.6 & 74.0 & 31.1 \\
\hline No. of responses & 237 & 141 & 194 & 153 & 200 & 203 & 242 & 183 \\
\hline \multicolumn{9}{|l|}{$\begin{array}{l}\text { If you had asked } 5 \text { to } 10 \text { percent more for your property, what would the } \\
\text { likely outcome have been? }\end{array}$} \\
\hline It wouldn't have been sold. & 21.3 & 23.5 & 23.4 & 27.1 & 31.1 & 27.7 & 32.5 & 26.1 \\
\hline It would have sold but it would have taken much more time. & 44.9 & 47.1 & 46.9 & 40.7 & 54.1 & 38.6 & 37.2 & 39.3 \\
\hline $\begin{array}{l}\text { If buyers had to pay that much they might not be able to obtain financing } \\
\text { (a buyer cannot obtain financing unless an appraiser confirms the } \\
\text { worth of the property). }\end{array}$ & 7.9 & 4.1 & 9.4 & 6.8 & 0.0 & 4.8 & 9.3 & 8.7 \\
\hline It probably would have sold almost as quickly. & 24.7 & 23.5 & 17.2 & 20.3 & 11.5 & 26.5 & 16.3 & 21.7 \\
\hline Other & 1.1 & 1.5 & 3.1 & 5.1 & 3.3 & 2.4 & 4.7 & 4.4 \\
\hline No. of responses & 89 & 68 & 64 & 59 & 61 & 83 & 43 & 46 \\
\hline
\end{tabular}


Table 13. Survey Responses on Excess Demand and Upward Rigidity in Asking Prices, 1988 and 2003a (continued)

Percent of responses except where stated otherwise

\begin{tabular}{|c|c|c|c|c|c|c|c|c|}
\hline \multirow[b]{2}{*}{ Question } & \multicolumn{2}{|c|}{ Los Angeles } & \multicolumn{2}{|c|}{$\begin{array}{c}\text { San } \\
\text { Francisco }\end{array}$} & \multicolumn{2}{|c|}{ Boston } & \multicolumn{2}{|c|}{ Milwaukee } \\
\hline & 1988 & 2003 & 1988 & 2003 & 1988 & 2003 & 1988 & 2003 \\
\hline \multicolumn{9}{|l|}{$\begin{array}{l}\text { If you answered that it would have sold almost as quickly, which of the } \\
\text { following (you can check more than one) explains why you didn't set } \\
\text { the price higher?a }\end{array}$} \\
\hline The property simply wasn't worth that much. & 32.4 & 25.8 & 27.3 & 23.1 & 38.5 & 13.5 & 25.0 & 13.3 \\
\hline $\begin{array}{l}\text { It wouldn't have been fair to set it that high; given what I paid for it, } \\
\text { I was already getting enough for it. }\end{array}$ & 16.2 & 25.8 & 22.7 & 61.5 & 15.4 & 54.1 & 31.3 & 46.7 \\
\hline I simply made a mistake or got bad advice; I should have asked for more. & 21.6 & 19.4 & 18.2 & 7.7 & 19.2 & 8.1 & 25.0 & 13.3 \\
\hline Other & 29.7 & 29.0 & 31.8 & 7.7 & 26.9 & 24.3 & 18.8 & 26.7 \\
\hline No. of responses & 37 & 31 & 22 & 26 & 26 & 37 & 16 & 15 \\
\hline \multicolumn{9}{|l|}{$\begin{array}{l}\text { In the six months prior to the time you first listed the property, did you } \\
\text { receive any unsolicited calls from a real estate agent or anyone else } \\
\text { about the possibility of selling your house? }\end{array}$} \\
\hline Yes & 71.9 & 69.1 & 59.0 & 55.6 & 38.7 & 53.0 & 43.2 & $\ldots{ }^{\mathrm{b}}$ \\
\hline No & 28.1 & 30.9 & 41.0 & 44.4 & 61.3 & 46.0 & 56.8 & $\ldots$ \\
\hline \multicolumn{9}{|l|}{ Approximate number of calls } \\
\hline Mean & 8.7 & & 5.0 & & 3.9 & & 2.7 & \\
\hline Standard error & 1.2 & & 0.3 & & 0.4 & & 0.2 & \\
\hline No. of responses & 89 & 68 & 61 & 63 & 62 & 83 & 48 & 44 \\
\hline
\end{tabular}

Source: Authors' survey described in the text.

a. Responses from buyers surveyed who had also sold a home. The sale is assumed to have occurred in the same metropolitan area as the purchase.

b. The question was not asked. 
over 20 percent of sellers in all markets in 2003, a substantially larger fraction than in 1998 except in Los Angeles, where it stayed the same.

An amazing number of the 2003 respondents-in fact, a majority in San Francisco and Boston, a near majority in Milwaukee, and 26 percent in Los Angeles - thought that charging more than they did would be unfair. On the other hand, the number who reported that their home was not intrinsically worth more than they were asking dropped in the latest survey compared with that in 1988.

\section{Downward Rigidity and Excess Supply}

An important question on which the survey sheds some light is, What happens in a bust? How do sellers respond to rising inventories and increasing time on the market? It is important first to point out that the housing market is not an auction market. Prices do not fall to clear the market quickly, as one observes in most asset markets. Selling a home requires agreement between buyer and seller. It is a stylized fact about the housing market that bid-ask spreads widen when demand drops, and the number of transactions falls sharply. This must mean that sellers resist cutting prices.

Table 14 supports the notion that sellers lower their asking prices only as a last resort. A majority of respondents in all cities and in both years of the survey argue that the best strategy in a slow market is to "hold up until you get what you want." Only a small minority reported that they would have "lowered the price until I found a buyer." In addition, large majorities ranging from 79 percent in San Francisco in 1988 to 93 percent in post-boom Boston reported having reservation prices.

There is clear evidence that such resistance prevents home prices from falling at the onset of a down period and that, if the underlying fundamentals come back quickly enough, they can prevent a bubble from bursting. Instead, the danger when demand drops in housing markets is that the volume of sales may drop precipitously. This could do more damage to the U.S. economy today than a modest decline in prices.

\section{A Model of Speculative Bubbles in Housing}

Buyers and sellers in the housing market are overwhelmingly amateurs, who have little experience with trading. High transactions costs, 
Table 14. Survey Responses on Excess Supply and Downward Rigidity in Asking Prices, 1988 and 2003 ${ }^{a}$

Percent of responses except where stated otherwise

\begin{tabular}{|c|c|c|c|c|c|c|c|c|}
\hline \multirow[b]{2}{*}{ Question } & \multicolumn{2}{|c|}{ Los Angeles } & \multicolumn{2}{|c|}{$\begin{array}{l}\text { San } \\
\text { Francisco }\end{array}$} & \multicolumn{2}{|c|}{ Boston } & \multicolumn{2}{|c|}{ Milwaukee } \\
\hline & 1988 & 2003 & 1988 & 2003 & 1988 & 2003 & 1988 & 2003 \\
\hline \multicolumn{9}{|l|}{$\begin{array}{l}\text { Since housing prices are unlikely to drop very much, the best strategy in a } \\
\text { slow market is to hold up until you get what you want for a property. }\end{array}$} \\
\hline Agree & 69.0 & 64.0 & 69.6 & 69.0 & 57.5 & 51.2 & 50.6 & 61.9 \\
\hline Disagree & 31.0 & 36.0 & 30.4 & 31.0 & 42.5 & 48.8 & 49.4 & 38.1 \\
\hline No. of responses & 174 & 111 & 148 & 129 & 160 & 166 & 180 & 147 \\
\hline \multicolumn{9}{|l|}{$\begin{array}{l}\text { If you had not been able to sell your property for the price that you } \\
\text { received, what would you have done? }\end{array}$} \\
\hline $\begin{array}{l}\text { Left the price the same and waited for a buyer, knowing full well that it } \\
\text { might have taken a long time }\end{array}$ & 42.0 & 32.3 & 38.7 & 29.5 & 32.8 & 21.7 & 32.6 & 39.5 \\
\hline Lowered the price step by step hoping to find a buyer & 20.5 & 32.3 & 38.7 & 26.7 & 42.6 & 47.0 & 20.9 & 30.2 \\
\hline Lowered the price till I found a buyer & 4.5 & 7.7 & 3.2 & 11.5 & 4.9 & 12.0 & 7.0 & 9.3 \\
\hline Taken the house off the market & 18.2 & 21.5 & 17.7 & 27.9 & 11.5 & 15.7 & 27.9 & 16.3 \\
\hline Other & 14.8 & 6.2 & 1.6 & 4.9 & 8.2 & 3.6 & 11.6 & 4.6 \\
\hline No. of responses & 88 & 65 & 62 & 61 & 61 & 83 & 43 & 43 \\
\hline \multicolumn{9}{|l|}{$\begin{array}{l}\text { If you answered that you would have lowered your price, is there a limit } \\
\text { to how far you would have gone if the property still hadn't sold? }\end{array}$} \\
\hline Yes & 81.8 & 85.7 & 78.9 & 81.3 & 93.1 & 87.7 & 87.5 & 90.3 \\
\hline No. of responses & 33 & 35 & 38 & 32 & 29 & 57 & 16 & 32 \\
\hline
\end{tabular}

Source: Authors' survey described in the text.

a. Responses from buyers surveyed who had also sold a home. The sale is assumed to have occurred in the same metropolitan area as the purchase. 
moral hazard problems, and government subsidization of owner-occupied homes have kept professional speculators out of the market. These amateurs are highly involved with the market at the time of home purchase and may overreact at times to price changes and to simple stories, resulting in substantial momentum in housing prices.

Shiller argues that speculative bubbles are caused by "precipitating factors" that change public opinion about markets or that have an immediate impact on demand, and by "amplification mechanisms" that take the form of price-to-price feedback. ${ }^{20}$ A number of fundamental factors can influence price movements in housing markets. On the demand side, demographics, income growth, employment growth, changes in financing mechanisms or interest rates, as well as changes in locational characteristics such as accessibility, schools, or crime, to name a few, have been shown to have effects. On the supply side, attention has been paid to construction costs, the age of the housing stock, and the industrial organization of the housing market. The elasticity of supply has been shown to be a key factor in the cyclical behavior of home prices.

The cyclical process that we observed in the 1980s in those cities experiencing boom-and-bust cycles was that general economic expansion, best proxied by employment gains, drove demand up. In the short run those increases in demand encountered an inelastic supply of housing and developable land, inventories of for-sale properties shrank, and vacancy declined. As a consequence, prices accelerated. This provided the amplification mechanism as it led buyers to anticipate further gains, and the bubble was born. Once prices overshoot or supply catches up, inventories begin to rise, time on the market increases, vacancy rises, and price increases slow, eventually encountering downward stickiness.

With housing, a significant precipitating factor may be employment gains, if only because they are highly visible. Employment releases occur on the first Friday of each month, with state data released somewhat later. Both national and state releases by the BLS receive dramatic fanfare in the press. In all three of the cities with volatile prices, substantial employment gains and falling unemployment preceded the upward acceleration of home prices during both booms.

The predominant story about home prices is always the prices themselves; the feedback from initial price increases to further price increases 
is a mechanism that amplifies the effects of the precipitating factors. If prices are going up rapidly, there is much word-of-mouth communication, a hallmark of a bubble. The word of mouth can spread optimistic stories and thus help cause an overreaction to other stories, such as stories about employment. The amplification can also work on the downside as well. Price decreases will generate publicity for negative stories about the city, but downward stickiness is encountered initially.

The amplification mechanism appears to be stronger in the glamour cities that were undergoing rapid price change at the time of our surveys than in our control city of Milwaukee. We saw in our survey results that talk about real estate is more frequent in those cities and that excitement is stronger there. Presumably this greater talk and excitement have something to do with the greater price volatility seen historically in the glamour cities, leading to greater public interest and concern with movements in real estate prices. Thus real estate price volatility can be self-perpetuating: once started, it generates more public attention and interest, and thus more volatility in the future.

Longer-run forces that come into play tend eventually to reverse the impact of any initial price increases and the public overreaction to them. New construction can bring some new housing online in the space of about a year. The United States now has a highly sophisticated national construction industry, dominated by national firms such as Pulte Homes, Lennar Corporation, and Centex Corporation. These firms are capable of moving their operations into a city quickly if they perceive the ability to build homes for less than the going price. However, there are important barriers to their moving into certain cities, as executives from these firms will animatedly tell you. In many mature cities there is no place to build, and obtaining permits can be long and costly. Case has argued that differences in supply elasticity across cities explained a larger percentage of price changes than do demographics. ${ }^{21}$ Clearly, prices of homes can go up more rapidly than building costs only if supply is inelastic at least in the short run.

Zoning restrictions are an important barrier to the construction of new homes. These restrictions prevent more intensive use of available land, for example by building more closely spaced houses or taller high-rise apartment buildings. Edward Glaeser and Joseph Gyourko have shown a 
close correlation across U.S. cities between a measure of zoning strictness derived from the Wharton Land Use Control Survey and the ratio of existing housing prices to the cost of new construction. ${ }^{22}$ They found that there is relatively little correlation between population density and home prices, even though economic theory might seem to suggest such a correlation. Thus zoning has been fundamental in limiting the supply of housing.

Even if shortages of places to build are long lasting, in the longer run positive impulses to employment can, if there are barriers to the supply response, lead to outflow of industries that have little reason to stay in the city, thereby eventually reversing the high demand for homes. At the height of a boom, both labor supply and labor demand can be negative factors, with high home prices deterring workers from coming to an area and a labor shortage deterring industry from locating there. Moreover, retirees and families with children (who have higher housing demand) will tend eventually to leave high-price cities. Thus cities that have attracted certain industries and have seen a surge in employment eventually become more specialized: Silicon Valley, for example, has become almost exclusively a mecca for people who need to benefit from the synergies of the electronics industry.

This process can eventually reverse the price increases. This process of reversal, however, is hardly on the minds of most homebuyers, who, as we have seen, are preoccupied with relatively simplistic stories about housing when they consider their investments. The relatively poor performance of their city after the boom comes as a surprise to them.

Over long intervals in most states, the growth rate of home prices has tended to track growth in nominal income per capita. It is not surprising that this should be so, for two reasons. First, land zoned for new construction in scarce or important locations is fixed, and if people target a fraction of their income for the costs of a home, given fixed supply the price of that fixed land should increase with income. Second, construction costs, which are mostly labor costs, tend to track income per capita as well. Thus, over the period from 1980 to 2000, price growth in Los Angeles and price growth in Milwaukee have been about the same. But there is a big difference in the shorter-run behavior of prices in those two cities.

22. The zoning strictness measure is the length of time it takes for an application for rezoning to result in a building permit for a modest-sized single-family subdivision of fewer than fifty units (Glaeser and Gyourko, 2002). 
The upward trend in home prices that is implied by the growth rate of income per capita, along with the tendency for home price decreases to be slow and sluggish, has meant that relatively few citywide home price declines have been observed in history. More often one sees periods of flat real estate prices, where the ratio of price to income, or the ratio of price to the consumer price index, is falling but nominal prices themselves have not fallen. Outright price declines are much more salient in investor psychology than failures of prices to keep up with income. Thus popular culture has not identified bubbles as a problem in real estate, or did not until last year.

The popular impression has been that real estate is an investment that cannot lose money. The declines in prices in the early 1990s in many cities, documented for the first time in history by accurate real estate price indexes developed by us and others, have forever reduced the salience of this public impression, but, as our latest survey documents, the idea still lingers. There is also a popular impression that real estate is a candidate for the "best investment" that can be made (see top panel of table 12). Whether real estate is in fact the best possible investment is not something amenable to economic analysis, since one cannot measure the "dividend" in the form of housing services that homes offer. Presumably there is diminishing marginal utility to owning a bigger and bigger house, and so the psychic dividend declines with the amount of house purchased. The basic question that individuals must resolve is how big a house to buy, and the theory that "housing is always the best investment" is a poor clue to how to answer this question. Yet that theory has a salience that is quite strong in the current market.

\section{Is a Housing Bubble about to Burst?}

Clearly, one can construct an argument that home price increases nationally since 1995 have been driven by fundamentals. For more than forty states, income growth alone explains virtually the entire increase in housing prices, and falling interest rates have reduced financing costs sufficiently to keep the ratio of annual mortgage payments to income from rising even in the boom states of Massachusetts and California. In the vast majority of states, housing is actually more affordable than it was in 1995 . 
Nonetheless, our analysis indicates that elements of a speculative bubble in single-family home prices - the strong investment motive, the high expectations of future price increases, and the strong influence of wordof-mouth discussion-exist in some cities. For the three glamour cities we studied, the indicators of bubble sentiment that we documented in tables 8 and 9 remain, in general, nearly as strong in 2003 as they were in 1988. Some of these are surprisingly high in 2003, notably the ten-year expectations for future price change, where the average expected annual price increase is in the 13 to 15 percent range for all these cities. Even our fourth city, Milwaukee, is perhaps showing some bubble sentiment, for the expected annual price increase for the next ten years there is 11.7 percent.

All of the fundamental measures of bubble activity - the expectations, the sense of opportunity and urgency, the excitement and amount of talk-are generally down from their levels in 1988 in the glamour cities, but up from their levels of 1988 in Milwaukee. (Long-run expectations, however, are generally up substantially from 1988. If long-run expectations matter most, one might say that the 2003 exuberance is just as strong as the 1988 one.) Most people do not perceive themselves in 2003 as in the midst of a bubble, despite all the media attention to the possibility. However, neither did people perceive themselves to be in a bubble in 1988, after which real prices fell sharply in many cities.

Although these indicators do not suggest such strong evidence of a bubble as was observed in 1988 , it is reasonable to suppose that, in the near future, price increases will stall and that prices will even decline in some cities. We have seen that people are not as confident of real estate prices as they were even before the 1980s real estate bubble burst, and this lack of confidence may translate into an amplification of any price declines. Real home prices are already flat in Denver and Detroit, following periods of rapid growth. More declines in real home prices will probably come in cities that have been frothy, notably including some cities on both coasts of the United States, and especially those that have weakening economies. But declines in real estate prices might appear even in cities whose employment holds steady.

The consequences of such a fall in home prices would be severe for some homeowners. Given the high average level of personal debt relative to personal income, an increase in bankruptcies is likely. Such an increase could potentially worsen consumer confidence, creating a renewed interest in replenishing savings. 
Personal consumption expenditure, which has driven the economy so far in the current recovery, may drop, stalling the recovery. However, judging from the historical record, a nationwide drop in real housing prices is unlikely, and the drops in different cities are not likely to be synchronous: some will probably not occur for a number of years. Such a lack of synchrony would blunt the impact on the aggregate economy of the bursting of housing bubbles. 


\section{Comments and Discussion}

Christopher Mayer: It is an honor to discuss this paper. I had not yet started graduate school when Karl Case and Robert Shiller wrote their first paper together. After finishing graduate school, I took my first job at the Federal Reserve Bank of Boston, where Case was then a visiting scholar. He and I had many discussions about the housing market, and we coauthored several papers. The output of those conversations remains with me today.

I will begin with a brief summary of the paper's findings, focusing on my interpretations of the authors' principal results and on the strengths (and limitations) of their data. I will also examine why there is currently a popular perception of a housing market bubble. On this point I will consider a couple of issues that get less attention in this paper and that might give a slightly different perspective on its findings, namely, the role of nominal interest rates and expected inflation. I will conclude with some comments about whether we should be worried about a housing bust today.

SUMMARY OF FINDINGS. The first striking fact to note in this paper is how stable the home price-to-income ratio is in many parts of the country (the authors' tables 1 and 2). In most states the difference between the minimum and the maximum price-to-income ratio is between 10 and 20 percent of its median value over the sample period. These numbers suggest a strong relationship, with little variation, between home prices and a simple (univariate) proxy for demand. These statistics argue against the popular perception (including that of many economists) that housing markets are excessively volatile. 
But the data also show that, in a few states, the home price-to-income ratio is quite volatile. Case and Shiller examine eight such states and show that the fundamentals appear to explain much less of the variability in home prices (or the home price-to-income ratio) over time. Although one might say that eight out of fifty states is not a large number, these eight states include the most valuable real estate in the country. I would not be surprised if these eight states (which include California, Massachusetts, New Jersey, and New York) account for a majority of total home value in the United States.

Another difference between these eight states and the rest of the country is where the economies of those states stand today. In none of the eight states is the home price-to-income ratio as high as it was in the late 1980s. However, that fact in and of itself is not necessarily cause for optimism, because home prices fell in those eight states in the aftermath of the runup that led to those high ratios. At the same time, many of the other states, although their prices have been less volatile, have a home price-to-income ratio that appears at or near its historic peak in the Case and Shiller data.

Most of the paper describes results from two surveys of recent homebuyers that the authors conducted in 1988 and 2003 in four metropolitan areas. As one who has been citing their 1988 survey results for a long time, I was excited to discover that they had updated the survey. This is a great time to conduct a follow-up study, although it would have been even more interesting to see a comparison from a bust year in the early 1990s as well. In the previous survey I was always struck by the cross-sectional comparison between homeowners' high expectations of price appreciation in the booming metropolitan areas of Boston, Orange County, and San Francisco and the more moderate expectations of homeowners in Milwaukee.

When compared with the earlier survey results, the 2003 findings, with one real exception, are relatively unchanged. Although some of the numbers went up or down a little bit, most of the changes are likely to be within the standard error bounds from the previous findings. The exception is that a preponderance of the homebuyers in Milwaukee expressed higher expectations of home price appreciation than did Milwaukee homebuyers in the previous survey, despite the fact that Milwaukee home prices have not boomed to the same extent as those in the other locations surveyed. However, in discussions with the authors I learned that the differences in means that are cited in the paper are considerably more strik- 
ing than the differences in medians. The median expected appreciation in the Milwaukee sample for the next ten years is about 5 percent a year, and that for some of the other cities is 7 or 8 percent—still fairly high, but not quite as outlandish as the mean expectations, which exceed 10 percent in all four metropolitan areas in the 2003 survey.

Other results in the paper seem reasonable to me, even if they seem less so to the authors. Homeowners perceive housing to be a stable investment relative to the stock market. One reason is that they recognize that no matter what happens to the price of housing, they still get to live in their home. This observation makes a lot of sense when comparing housing with stocks, because stocks pay very low and variable (and sometimes no) dividends. So, when stock prices fall, as they have recently, owners of stocks are hurt. In contrast, the dividend in the housing market is tangible. Most of the financial return from a house comes from getting to live in the house, not from the expected capital gain. (After all, average real home prices increased just 1.2 percent a year between 1975 and 2000, according to data from OFHEO.) Whether or not the price of that house goes up or down, the owner still realizes consumption value. Academic economists debate how to measure that value, and how it co-varies with the value of housing. But, from the perspective of most homeowners, who cannot easily hedge their housing investments, that consumption flow is unchanged over cycles in the housing market. Todd Sinai and Nick Souleles have written a compelling paper showing how home ownership can serve as an effective hedge against real estate cycles and the volatility of rent, which suggests that homeowners may also get other benefits relative to renters in the housing market. ${ }^{1}$ Case and Shiller's survey suggests that some homeowners perceive the value of a home as coming from consumption, and that the housing market is less risky than the stock market. These findings seem perfectly reasonable for most U.S. homeowners.

Another major result from the survey (to which I will return at the end) is that home prices are sticky. This certainly appears to be true. I have done some work with David Genesove showing that loss aversion and liquidity constraints can help explain sticky home prices, at least during busts. ${ }^{2}$ A third factor appears to be that people are just very slow to adjust their reservation prices. This slow adjustment may have to do

1. Sinai and Souleles (2001).

2. Genesove and Mayer (1997 and 2001). 
with institutional factors, such as the use of lagged appraisals to set current asking prices.

The paper suggests that one should not expect large declines in home prices, even in the most volatile states, if demand for housing falls. However, there is some inconsistency between this claim and the observation that these states have volatile home price-to-income ratios. In addition, these are places where nominal housing prices have in fact fallen in the past. Finally, my previous work in this area suggests that even if prices are sticky, the number of transactions can fall considerably, which, as the paper notes, could lead to considerable macroeconomic distress.

TECHNICAL ISSUES. A few technical issues are worth considering, although they are not critical to interpreting the results in this paper. For example, the use of state-level home price indexes is likely to underestimate the volatility of home prices in metropolitan areas. However, reliable income data do not exist at the metropolitan level, which necessitates the state-level analysis. Also, the OFHEO home price indexes that are used for most of the states miss the high end of the market, because they are based on sales of homes with "conforming loans," which exclude the highest-priced homes in the country. Indexes from OFHEO may well understate the price increases for high-priced homes, which have clearly been larger relative to those for low-priced homes, and this bias might be greater in the highest-priced areas. So the OFHEO data almost certainly understate the extent of price increases and underestimate volatility, because the values of high-priced homes are typically more volatile than those of low-priced homes. ${ }^{3}$

Also, as John Quigley notes in his comment, supply clearly matters. However, I will start with the same premise that the authors implicitly do: that the supply of housing is inelastic, at least in the eight volatile states. If this assumption were not true, and the supply of housing were perfectly elastic, we would have nothing to talk about. Home prices would be driven by the sum of construction cost and the opportunity cost of land (that is, its value in agricultural use). The fact that any demand-side variables are correlated with home prices provides evidence that supply is not perfectly elastic.

Another issue relates to Case and Shiller's observation that consumers do not typically describe empirical evidence or use sophisticated ideas

3. Mayer (1993). 
when talking about the housing market. In fact, consumers have no choice, because there are no appreciable data available to them (or to researchers) that can be used to study local home prices. The authors started a wonderful company that generates high-quality local price indexes, but their data are not widely disseminated. When I go to the Internet to find home price indexes for individual metropolitan areas, the OFHEO data are the only data available. I cannot easily get data from Case, Shiller, and Weiss to describe local markets. And the typical real estate broker does not really understand what a price index is, let alone have any reliable data. So it is not very surprising that, in the stock market, people talk about price-earnings ratios, but in the housing market they do not. The data are not available. One could say that that is endogenous, but nonetheless, even sophisticated buyers and sellers are limited in this market by poor data.

WHY DO CONSUMERS “THINK" THERE IS A HOUSING BUbBLE? An issue that Case and Shiller raise early in the paper is the perception in the media that the United States is in a housing bubble. This perception is puzzling in that a lot of economists, at least, do not seem to see a lot of evidence of a bubble. Here I consider two related issues that might affect this perception: the role of interest rates and the role of expected inflation.

Many observers have commented that the housing market really is a regional or even a local market. That has certainly been true in the past. Yet in the last several years there has been much more of a common factor in the movement of home prices in many different parts of the country. Most observers point to historically low interest rates as that common factor.

When I have run regressions of home prices on the user cost of housing, I have typically found a remarkably low coefficient on user costs. That is, it seems as if, historically, housing purchase behavior and housing values have not been very responsive to changes in interest rates. (An alternative hypothesis is that user costs are poorly measured, which is probably true as well.) But the recent data on home prices reveal historically unprecedented patterns. I do not know of a previous recession in which home prices increased as the economy turned down. I see almost nothing else that one can point to besides interest rates to explain rising home prices at a time of falling employment and incomes. One implication is that, if interest rates rise from their current low levels, the housing market could suffer more broadly than it has in the past when interest rates rose. 
That home prices were rising in a recession must be related to the perception of a housing bubble. In the forty-two states with relatively stable home price-to-income ratios, that ratio is at or near its peak of the last thirty years in almost all. For the eight remaining, high-volatility states, the home price-to-income ratio is high, but not as high as it was in the late 1980s or early 1990s, just before home prices began a dramatic fall in these states. However, this fact might provide only limited comfort for homeowners in these states, because the past housing bust was severe in states such as California and Massachusetts.

Another, related fact is that the commercial real estate market exhibits a pattern similar to that in the housing market. Commercial real estate prices have been setting new highs even as rents have been falling. This is unusual in that the commercial real estate market rarely mirrors the housing market. Some observers have suggested that this represents another bubble, and many well-known commercial real estate owners have publicly announced that they are selling assets in the United States.

Figure 1 below shows real home prices nationally over roughly the last quarter century. (These data come from OFHEO, as do most of the data used in this comment, and so they are subject to the biases I discussed earlier.) What is striking in this figure is that, unlike in previous business cycles, home prices did not turn down in 2000 when the expansion ended. It is difficult to come up with convincing explanations for this fact. Strikingly, when I examine some of the explanations that other people have raised, it turns out that theory would predict the opposite effect.

INTEREST RATES AND REAL HOME PRICES. Consider today's historically low interest rates. The standard metric used to consider the impact of interest rates on real estate values is the user cost of housing, ${ }^{4}$ which is defined as the rental cost of a unit of housing divided by the price of housing, as follows:

$$
R_{H} / P_{H}=(1-M T R)\left(r+\pi^{e}+\tau_{p}\right)+\delta+\alpha-\pi_{H}^{e} .
$$

In words, the user cost equals 1 minus the marginal tax rate, multiplied by the nominal interest rate (which here is decomposed into the real interest rate $r$ plus expected inflation $\pi^{e}$ ) plus property taxes $\tau_{p}$. To this are added depreciation and a risk premium, and the expected rate of appreciation of housing is subtracted off.

4. Poterba (1984). 
Figure 1. Real Home Prices, 1975-2003

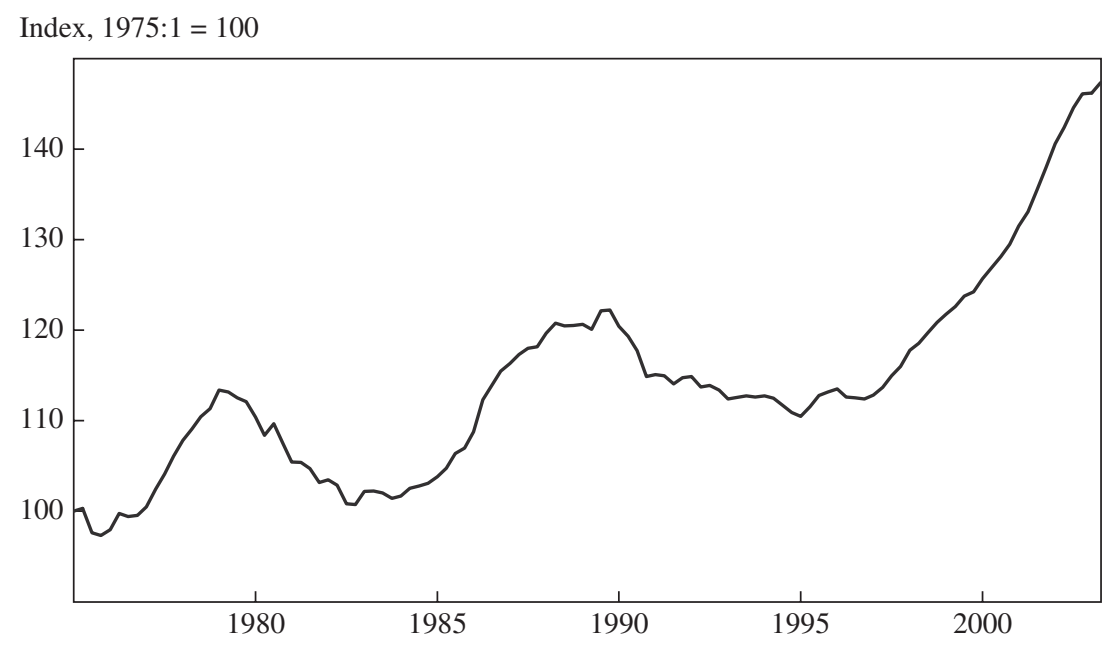

Source: Author's calculations.

In theory, one should expect that, before taxes, home price inflation $\left(\pi_{H}^{e}\right)$ will increase one for one with expected inflation in the economy as a whole $\left(\pi^{e}\right)$. Using that relationship and examining the user cost model further yields two interesting predictions. The first is that decreases in expected inflation lead to a higher user cost of housing and thus lower (real) home prices. The reason is that homeowners get to deduct nominal interest payments from taxable income. A decline in expected inflation by $\Delta \pi^{e}$ decreases the rate of growth of home prices by $\Delta \pi^{e}$ but lowers interest costs by only $(1-M T R) \Delta \pi^{e}$. Thus the net effect of a decline in expected inflation is to increase the after-tax user cost of housing.

Empirical evidence supports the opposite prediction: that higher expected inflation is associated with higher real home prices. James Poterba presented a Brookings Paper in 1991 showing that home price increases were relatively larger for higher-priced homes than for lowerpriced homes in the early 1980s, when expected inflation had increased. ${ }^{5}$ This evidence is consistent with the (after-tax) user cost model in that owners of higher-priced homes face a higher marginal tax rate and thus

5. Poterba (1991). 
Figure 2. Expected Rate of Inflation, 1971-2002

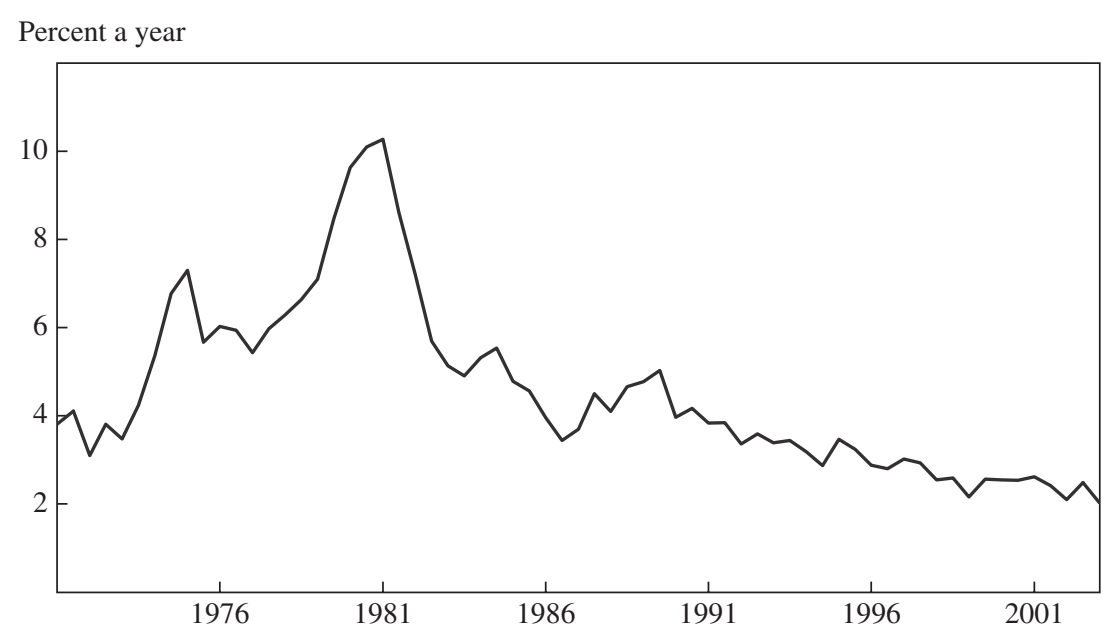

Source: Livingston Survey, Federal Reserve Bank of Philadelphia (www.phil.frb.org/econ/liv).

get a larger tax benefit from expected inflation than do owners of lowerpriced homes, many of whom do not even itemize their deductions and thus get no benefit from the tax deductibility of mortgage interest expense.

So, from a theoretical perspective, decreases in expected inflation should be bad for real home prices. My figure 2 presents data from the Livingston survey on expected inflation. These data show a slow and steady decline in expected inflation over the last fifteen years. Contrary to the popular perception, low expected inflation should be bad for the housing market, not good.

The survey results from the Case and Shiller paper provide no evidence that consumers have lowered their expectations of home price increases in line with lower expected inflation in 2003 relative to 1988. Expected annual inflation has declined from 5 percent to just under 2 percent today, according to projections of what the Livingston survey is likely to show for 2003. Yet consumers in the Case and Shiller survey seem to have had similar expectations of (nominal) home price increases in both 1988 and 2003. If anything, their expectations in 2003 are even higher. 
Figure 3. Thirty-Year Mortgage Rates, 1971-2003

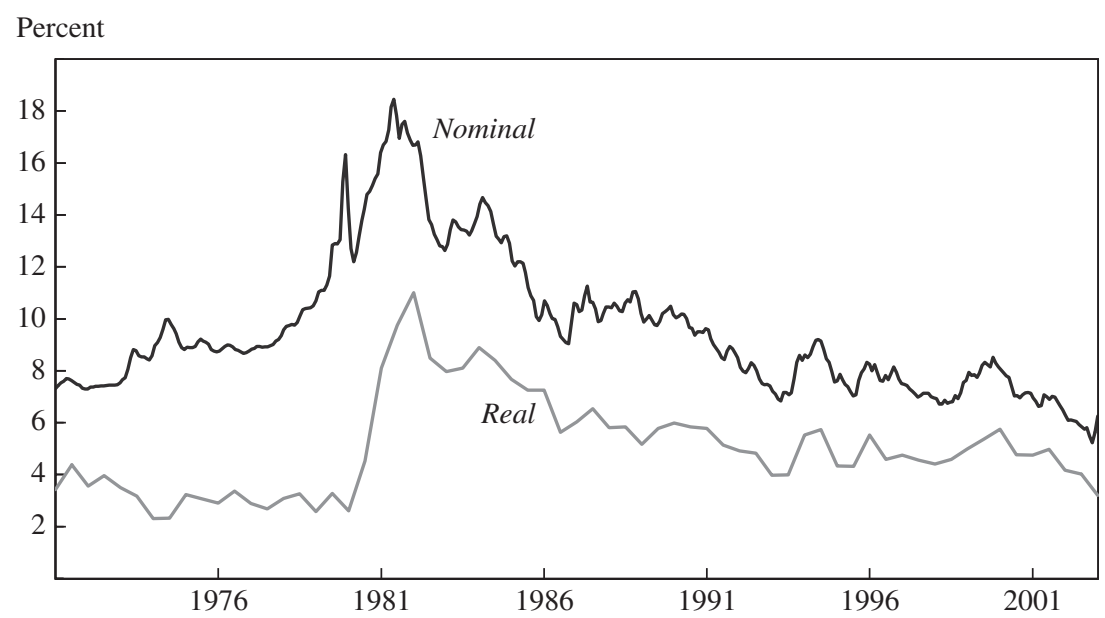

Source: Author's calculations.

Low expected inflation, then, cannot easily explain the rise in real home prices or consumers' predictions of a relatively high growth rate for home prices. Alternatively, one can also look at changes in real mortgage rates. After all, low real mortgage rates will lead to higher real home prices. My figure 3 traces nominal and real mortgage rates over the last thirty-one years. Although nominal rates are at or near historic lows, and real mortgage rates are low as well, real rates are not quite as low as they were for much of the 1970s. Of course, real mortgage rates have fallen in the last four years, mirroring the rise in real home prices.

The question is, Which should matter more, nominal rates or real rates? Or, alternatively, why might low nominal rates spur the housing market? As I mentioned earlier, regressions on historical data do not show an enormous impact of real interest rates on home prices, and real home prices have always fallen in previous recessions.

Low nominal interest rates are the only factor that I can point to that might explain the recent surge in home prices during a recession. One could argue that consumers are confusing nominal and real interest rates. One way that this might happen is if consumers (or lenders) target a fixed 
payment-to-income ratio. If consumers are liquidity constrained, lower nominal rates allow people to afford more housing.

A skeptic might point out that consumers have always been liquidity constrained, or at least that has been the conclusion of many academic studies. So what is different today? One possibility is that lenders have become much more aggressive and are willing to make loans to consumers who make very low down payments. Thus the down payment constraint no longer binds today; instead the income constraint is binding. But if this model is correct, the immediate conclusion is that as soon as nominal interest rates rise again, people will be able to afford less housing for a fixed payment-to-income ratio, and home prices will fall. Of course, this model assumes that home prices are not forward-looking.

There are many reasons to be skeptical of a model in which demand for housing is generated by a fixed payment-to-income ratio. For example, this model clearly does not hold when one examines cross-sectional data for U.S. metropolitan areas, which show that consumers do not have a fixed ratio of housing costs to income. Evidence suggests that homeowners and renters spend a higher percentage of income in high-priced areas like San Francisco than in low-priced ones like Milwaukee. So, at least cross-sectionally, this theory does not hold. Whether it is true within metropolitan areas, one could make some arguments. Although it is hard to believe in a target payment-to-income ratio completely, it is the only model that I can come up with that predicts that lower nominal interest rates will lead to higher home prices.

LONG-RUN HOME PRICE GROWTH RATES ACROSS CITIES. Case and Shiller point out that people in places where home prices have risen substantially, such as San Francisco and Boston, have higher expectations for home prices in the future than do people in places where home prices have risen slowly. These expectations are not as crazy as one might think. I am working on a research project with Joseph Gyourko and Todd Sinai examining the factors that lead to long-run differences in home price appreciation across U.S. metropolitan areas. Using census data from 1940 to 1970 , we show that, nationwide, real home prices increased by 2 percent a year on average, whereas real home prices in San Francisco and Boston grew by 3.9 percent and 3.1 percent a year, respectively. Far from being a temporary trend, these patterns accelerated between 1975 and 2000, according to data from OFHEO, when real home prices rose annually by 4.6 percent in San Francisco, 3.4 percent in Boston, and only 
1.2 percent for the United States as a whole. ${ }^{6}$ Yet rising home prices are not a fact of life in all places. Real home prices fell in cities such as Houston, Fort Worth, Fort Lauderdale, and West Palm Beach.

Since 1975 the real price of housing in San Francisco relative to the rest of the country has gone up 250 percent, which a skeptic might say is unprecedented, except that the same thing happened in the previous thirty years as well. San Francisco has been a place where home prices have continued to go up at above-average rates. Given this sixty-year trend, it is not unreasonable for consumers to expect this pattern to continue. ${ }^{7}$

IS A BUBbLE ABOUT TO BURST? What about the question that matters most at the end of the day: Will real home prices fall? I think there are warning signs out there. The survey evidence looks pretty consistent. The level of home prices as well as the home price-to-income ratio is high in many places.

If fixed payment-to-income ratios are at all important in the mortgage market, to lenders or borrowers, then any appreciable increase in mortgage rates (or any decrease in lending or tightening of mortgage standards) could have a negative impact on home prices. Although historical data would not predict a decline in home prices, there may be reasons why the situation is different now than in the past.

The first sign of a decline in demand for housing would be a fall in sales of single-family houses. Case and Shiller argue that nominal home price declines are rare and that declines in sales volume are more common. Yet although nominal home prices have never fallen at the national level, nominal prices have fallen in many metropolitan areas.

Case and Shiller suggest that policymakers should look at changes in sales volume if demand for housing falls. Even if sales volume falls before prices do, eventually prices will catch up. This observation is based on extensive research that Genesove and I have done in the Boston condominium market, where prices fell 40 percent in three years. ${ }^{8}$ Although asking prices were sticky at first, and homeowners preferred to

6. Preliminary census data from 1970 to 2000 confirm the patterns from the OFHEO data.

7. Our working paper will consider the economic reasons behind these facts, differentiating between production factors, such as agglomeration, and the consumption benefits of living in certain "superstar cities" like San Francisco and Boston.

8. Genesove and Mayer (1997). 
leave their home on the market rather than cut their asking price, eventually asking prices did catch up to the market.

In the Dallas condominium market, nominal prices fell almost 60 percent during the bust. In the Boston area, nominal prices in the overall housing market fell about 17 percent over three years. Thus nominal home prices can fall. The question is what is going on with the underlying economics. I wish I were a little more confident in the underlying economics of the housing market right now.

John M. Quigley: This paper by Karl Case and Robert Shiller makes provocative and sober reading in an economy mired in a postrecession nonrecovery and in which the implications of recent changes in tax and expenditure policies are just beginning to be sorted out. The authors raise the question of whether the recent run-up in the U.S. housing market is a manifestation of an irrational bubble, which will put the economy at some risk when it is eventually popped. In contrast to most of the recent literature in the bubble genre (and there has been a lot), this paper presents some original empirical analysis that is relevant, at least arguably, to the existence of a bubble in asset prices.

The paper makes three contributions. First, it clears the air by defining what an asset bubble really is. In much popular discussion and in the analyses presented in the financial press, abnormal price increases alone are sufficient to signify a bubble in the asset market. Case and Shiller suggest instead that an asset bubble appears when current prices depend upon expectations of future price increases. In this circumstance, when expectations change-perhaps on the basis of rumor or a mere shred of hard information-current prices may decline precipitously. Thus, measuring expectations is relevant. Second, the authors document recent trends in home prices at the state level and the course of home prices, home price changes, and income-to-home price ratios. For forty-two of the fifty states, the course of income is sufficient to explain price movements. For the eight remaining states, other economic variables add explanatory power, but these variables (what the authors call the "fundamentals") yield forecasts of home prices for 2000-02 that are lower than those actually observed.

Third, and most important, Case and Shiller report the results of a survey mailed to 500 home purchasers in four different metropolitan areas. 
The authors document the buyers' expectations and market perceptions and provide a wealth of survey information about what people say they think when considering buying a home.

Case and Shiller show that investment motives are clearly important among home buyers, although they remark somewhat bizarrely that this is a "defining characteristic of a housing bubble." They document that perceptions of risk are real and that risk is perceived to be more important in 2003 than it appeared to be in similar research they conducted in 1988.

Case and Shiller also document that recent homebuyers expected substantial price increases during their first year of occupancy, even in Milwaukee, and that they expected really amazing ten-year gains. Average one-year price increases are expected to be 7 to 11 percent. Average tenyear price expectations are a good bit higher, about 12 to 16 percent a year in these markets. People also generally view housing investment as an escalator-if you don't buy now, you won't be able to buy later.

The findings and the accompanying discussion make fascinating reading, and the authors are to be congratulated for their hard work in data collection and presentation. I do think the authors greatly overinterpret the consistency of their findings with the presence of an asset bubble, however.

Consider the dominant motive for house purchase-investment-and the escalator nature of the investment. Case and Shiller interpret these survey responses as evidence of a bubble in the current market. But ever since the Federal Housing Administration and the institution of the fixedrate, level-payment, self-amortizing mortgage came into being, home buying has been like a Christmas club: it represents a long-term payment contract with serious penalties for not following through with regularly scheduled investments. The payments are for "shelter," and the "investment" is painless. Of course, the housing market is an escalator. It is impossible to force yourself to save enough money so that you can buy the home tomorrow. These psychological aspects of the housing contract and saving behavior do not depend upon any price appreciation at all. Price increases are just a bonus. This is what your father told you.

Consider the perception that housing is a risky investment. Case and Shiller seem to interpret this as evidence of a bubble. But housing is the largest item in most household portfolios, and no methods are widely available to hedge the concentrated risk. It would be ironic if these two 
scholars should claim that this risk is a manifestation of an asset bubble, since both have been at the forefront in devising derivatives so that consumers may diversify the risks of homeownership.

The evidence on price expectations is quite disturbing, especially the fact that people think annual ten-year price increases will exceed one-year price increases. I do wonder if this is a manifestation of a bubble, or just the popular misunderstanding of compound interest. Might the response have been different if the equivalent question had been asked: Do you think your home will quadruple in value in nine years?

My interpretation of their conclusion is "Despite popular discussion of housing bubbles, most buyers in these four markets do not perceive one currently."

The big reason for concern about price increases for housing assets is the perceived analogy between the run-up and crash in the stock market and the current price increases experienced in the housing market. How compelling is that analogy?

The long-run relationship between housing costs and construction costs casts doubt on the analogy. The average price of new housing moved in tandem with engineering measures of housing construction costs (excluding land) until about 1987. Thereafter the price of newly built housing began to increase. By the end of the 1990s, new houses cost about 25 percent more than construction costs. ${ }^{1}$ Have we had a housing bubble for the past fifteen years?

I think that there are at least eight reasons to question the existence, or at least the importance, of a bubble in the housing market in 2003. First, housing demand is sensitive to income. Case and Shiller discuss the role of income in detail. Based on their state-by-state analysis, in only a couple of states-but big ones-is there any divergence seen between incomes and housing prices.

Second, housing demand is sensitive to price. The user cost of capital is the annual price at which these assets are enjoyed by homeowners. These costs include depreciation and maintenance, property taxes, real interest rates, federal income tax rates, the rate of capital gains, and inflation. Steven Raphael and I have estimated the course of user costs during the past quarter century. ${ }^{2}$ Even if one ignores capital gains, the trends are

1. See Quigley and Raphael (forthcoming).

2. Quigley and Raphael (forthcoming). 
clear. Well before the recent and substantial reductions in mortgage interest rates, user costs had been declining. In fact, user costs have declined secularly since about 1980 . When costs decline, the demand for an asset goes up.

Third, there is reason to believe that household formation, population aging, and immigration will increase the demand for shelter, for dwellings, and for owner-occupied housing. Forecasts are for 1.2 million new households a year to be created over the next decade. ${ }^{3}$ These trends can be expected to stimulate demand for housing, as older households continue to resist downsizing, as the rapidly growing demand for homeownership increases, and as the "echo boomers" (the children of the babyboom generation) enter the market. One celebrated error of the late 1980s, the forecast of a 47 percent fall in housing prices, ${ }^{4}$ arose because these kinds of demographic changes were ignored.

Fourth, the operation of land markets and the spatial concentration of growing metropolitan areas make built-up areas in desirable housing markets even more valuable. Most of the growth in metropolitan areas, indeed most of the economic activity in America, is coastal. Coastal metropolitan areas are not like the concentric circles of housing markets shown in textbooks. For a given amount of economic activity, the extensive margin is farther out from the city center. Savings in transport costs and increases in amenities are greater for close-in properties. Prices get bid up to reflect these transport savings and amenity differences.

Furthermore, most of these concentrations of growth are in the South and the West. For a variety of reasons to which Case and Shiller allude, it is almost illegal to build new dwellings in the West, especially in California. California has smart growth and growth controls. There are moratoriums on new construction-it is hard for a developer to build until you get as far inland as the Central Valley.

Fifth, in the housing market more than in other asset markets, the timing of transactions is affected by a reluctance to realize losses. The tradeoff between the selling price of a dwelling and time on the market is well recognized, and the other discussant for this paper has documented loss aversion. ${ }^{5}$ Housing prices are sticky downward. Prices are slow to decline.

3. Joint Center for Housing Studies (2003).

4. Mankiw and Weil (1989).

5. Genesove and Mayer (2001). 
Sixth, transactions costs are higher in this market than in other asset markets, such as the market for equity shares or for tulip bulbs. The turnover rate for publicly traded stocks is fifteen times the rate for houses. Selling costs are high (5 or 6 percent in brokerage), moving costs are high, and the psychological costs of moving among neighborhoods, schools, and so on are not trivial. It should come as no surprise that there are few day traders in housing.

Seventh, none of these intertemporal price comparisons take into account quality improvements in housing. Quality improvements are reckoned at about 1.3 percent a year. This affects the comparison and interpretation of price changes, at least in the longer run.

Eighth, markets are local. The fortunes of real property are intimately connected to the goods and services produced in different metropolitan areas, and the specialization of cities varies. (There are hints of this in the blunt state-by-state regressions presented by Case and Shiller.) Recall that the closest thing to a real and precipitous decline in housing prices in recent decades was the Texas bust of the late 1980s. Oil had gone from an average of $\$ 18$ a barrel in 1979 to an average of $\$ 35$ a barrel in 1981, and single-family housing construction tripled shortly thereafter. Then oil prices crashed, and so did housing prices. This was an oil price bubble, perhaps, but hardly a housing bubble. Asset prices are only imperfectly correlated across markets, making large aggregate declines unlikely. During the past two decades, 58 of the 100 largest metropolitan areas had at least one one-year price decline of 10 percent or more. But in only one year did aggregate U.S. housing prices decline-by 0.9 percent in 1991.

A 10 percent decline in housing values nationally would thus require some very large declines in some markets. But suppose a 10 percent decline did occur. How would this affect household consumption? As of last December, the aggregate value of residential housing was estimated at $\$ 13.7$ trillion, and aggregate mortgage debt was a bit over $\$ 6$ trillion, leaving $\$ 7.6$ trillion in equity. A 10 percent national decline in home values would reduce equity by $\$ 1.4$ trillion, to $\$ 6.2$ trillion. This would reduce aggregate homeowner equity to its level at the end of 1999.

To estimate the effects of such a decline on consumption, one can apply one's preferred wealth effect coefficients to this equity change. My favorite is the 0.5 to 1.0 percent estimate of Case, Quigley, and Shiller. ${ }^{6}$

6. Case, Quigley, and Shiller (2001). 
This works out to at most a reduction of $\$ 14$ billion in spending, or something like a reduction of one-sixth of 1 percent of annual consumer spending. This is not trivial, but it is not a large effect either.

General discussion: The authors' interpretation of the survey responses received considerable attention. Martin Baily disagreed with the authors' view that respondents' answers to certain questions reflected confusion, because the distinction in the questions between levels and rates of change was not as clean as the authors suggested. Home prices in regions with inelastic supply should be expected to rise more rapidly in response to growing demand than prices in regions with elastic supply. And it seems quite reasonable for respondents to assume that supply is relatively inelastic in cities where "there is just not enough land available." Growth in income per capita, for example, should be expected to have a greater effect on home prices in San Francisco than in Houston. Similarly, it seems quite reasonable for respondents to view the phrase "because lots of people want to live here" as indicating expected future growth in housing demand. Hence Baily did not regard the responses as necessarily revealing confusion between levels and rates of change. He added that, with sticky prices, even a demand shock that shifts the long-run equilibrium level of prices would be expected to lead to a higher rate of growth of prices over the short run. Alan Blinder supported the use of household surveys to try to understand whether a bubble psychology underlay the housing boom in the glamour states. But he agreed that the wording of some of the questions about simple theories made it difficult for respondents to know whether a statement was about the level or the rate of change. Indeed, he thought that many of his students would not have been sensitive to the difference without tutoring.

Various panelists criticized the empirical analysis of the importance of fundamentals in determining home prices. William Brainard believed the authors had not treated interest rates adequately. He was puzzled that the equations explaining changes in prices did not use first differences of variables in the level equations. In particular, they used the level of the mortgage rate in both the level and the change equations. Brainard wondered whether the change in the mortgage rate would do a better job of explaining the change in price. Agreeing with Baily, Jeffrey Frankel noted that variables such as population and growth in income per capita should have larger effects in regions with relatively inelastic housing 
supply. He suggested using a panel regression that allowed the coefficients on variables such as growth in income per capita and population to differ across regions, but only by a common factor. Blinder would have liked to know more about trends in the purchase price-to-rental ratio. In cities like San Francisco stocks of rental and owner-occupied housing are quite similar in character. In these circumstances, rental income and its rate of growth may be good measures of the value of housing services of owner-occupied houses. Alan Auerbach agreed that looking at the priceto-rental ratio would be informative. Rising prices alone do not prove the existence of a bubble; a bubble exists only if prices increase more than what the economic fundamentals justify. A simple way to check this would be to see if the price-to-rental ratio is consistent, given interest rates, with the rate of growth of rentals.

Benjamin Friedman noted that the sample of respondents apparently included both first-time buyers and households that are trading up or down. He would have liked to see questions that clearly distinguished between these two groups, for whom the implications of expectations of rapidly rising prices are obviously quite different. Christopher Sims observed that the $R^{2}$ between two slowly moving series is expected to be very high. Because income is a very stable time series, the fact that $R^{2} \mathrm{~s}$ are high in markets where volatility is low, and lower in more volatile markets, adds little to the discussion. 


\section{References}

Bewley, Truman F. 2002. "Interviews as a Valid Empirical Tool in Economics." Journal of Socioeconomics 31(4): 343-53.

Case, Karl E. 1986."The Market for Single-Family Homes in the Boston Area." New England Economic Review (May/June): 38-48.

1994. "Land Prices and House Prices in the United States." In Housing Markets in the United States and Japan, edited by Yukio Noguchi and James M. Poterba. Cambridge, Mass.: National Bureau of Economic Research.

Case, Karl E., and Robert J. Shiller. 1987. "Prices of Single-Family Homes Since 1970: New Indexes for Four Cities." New England Economic Review (September/October): 45-56.

- 1988. "The Behavior of Home Buyers in Boom and Post-Boom Markets." New England Economic Review (November/December): 29-46.

. 1989. "The Efficiency of the Market for Single-Family Homes." American Economic Review 79(1): 125-37.

. 1990. "Forecasting Prices and Excess Returns in the Housing Market." American Real Estate and Urban Economics Association Journal 18(3): 253-73.

- 1994. "A Decade of Boom and Bust in the Prices of Single-Family Homes: Boston and Los Angeles: 1983 to 1993." New England Economic Review (March): 40-51.

Case, Karl E., John M. Quigley, and Robert J. Shiller. 2001. "Comparing Wealth Effects: The Stock Market vs. the Housing Market." Working Paper 8606. Cambridge, Mass.: National Bureau of Economic Research (November).

Dillman, Don A. 1978. Mail and Telephone Surveys: The Total Design Method. John Wiley \& Sons.

Follain, James R., and Stephen Malpezzi. 1981. "Are Occupants Accurate Appraisers?" Review of Public Data Use 9(1): 47-55.

Friedman, Milton. 1953. Essays in Positive Economics. University of Chicago Press.

Genesove, David, and Christopher Mayer. 1997. "Equity and Time to Sale in the Real Estate Market." American Economic Review 87(3): 255-69.

- 2001. "Loss Aversion and Seller Behavior: Evidence from the Housing Market." Quarterly Journal of Economics 116(4): 1233-60.

Glaeser, Edward L., and Joseph Gyourko. 2002. "The Impact of Zoning on Housing Affordability." Working Paper 8835. Cambridge, Mass.: National Bureau of Economic Research (March).

Goodman, John L., Jr., and John B. Ittner. 1992. "The Accuracy of Home Owners' Estimates of House Value.” Journal of Housing Economics 2(4): 339-57.

Joint Center for Housing Studies. 2003. The State of the Nation's Housing Market. Cambridge, Mass.: Harvard University. 
Kain, John F., and John M. Quigley. 1972. "Note on Owners Estimate of Housing Value." Journal of the American Statistical Association 67(340): 803-06.

Malpezzi, Stephen. 1999. "A Simple Error Correction Model of House Prices." Journal of Housing Economics 8(1): 27-82.

Mankiw, N. Gregory, and David Weil. 1989. "The Baby Boom, the Baby Bust, and the Housing Market." Regional Science and Urban Economics 21(4): $547-52$.

Mayer, Christopher J. 1993. "Taxes, Income Distribution and the Real Estate Cycle: Why All Houses Do Not Appreciate at the Same Rate." New England Economic Review (May/June): 39-50.

Poterba, James. 1984. "Tax Subsidies to Owner-Occupied Housing: An AssetMarket Approach." Quarterly Journal of Economics 99(4): 729-52.

_ 1991. "House Price Dynamics: The Role of Tax Policy and Demographics." BPEA, 1991:2, 143-203.

Quigley, John M., and Steven Raphael. Forthcoming. "Is Housing Unaffordable? Why Isn't It More Affordable?" Journal of Economic Perspectives.

Shiller, Robert J. 2000. Irrational Exuberance. Princeton University Press.

Sinai, Todd M., and Nicholas S. Souleles. 2001. "Owner Occupied Housing as a Hedge against Rent Risk." Working Paper. University of Pennsylvania (January). 